\begin{tabular}{|c|c|c|}
\hline $\begin{array}{l}\text { FATIH } \\
\text { SULTAN } \\
\text { MEHMET } \\
\text { VAKK UNIIVERSIESI } \\
2010\end{array}$ & $\begin{array}{l}\text { FSM İlmî Araştırmalar Insan ve Toplum Bilimleri Dergisi } \\
\text { FSM Scholarly Studies Journal of Humanities and Social Sciences } \\
\text { Sayı/Number } 14 \text { Yıl/Year } 2019 \text { Güz/Autumn } \\
\text { (C2019 Fatih Sultan Mehmet Vakıf Üniversitesi }\end{array}$ & 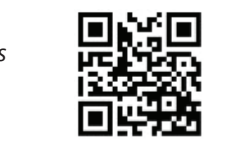 \\
\hline DOI: & http://dergipark.org.tr/fsmia & http://dergi.fsm.edu.tr \\
\hline Araştırma Makalesi / Research Article & Geliş Tarihi / Received: 04.10.2019 Kabul Tarihi / Accepted: 22.11.2019 & FSMIAD, 2019; (14): 399-434 \\
\hline
\end{tabular}

\title{
İslâm Hukuk Tarihinde Yaşamayan Sünnî Mezhepler ve Fuat Sezgin'in Tasnifi
}

Hüseyin Okur

\section{Öz}

İslam hukuk tarihinde müçtehit imamlar dönemi olarak bilinen hicri II. yüzyıl ile IV. asrın ortalarına kadar süren dönem, bilinen dört fikıh mezhebinin yanında diğer sünnî mezheplerin de teşekkül ettiği dönem olmuştur. Sayıları onlarca olan bu mezheplerin hemen hemen hepsi, siyasi ve sosyo-kültürel etkenlerden ötürü varlıklarını sürdürememiş, günümüze ulaşamamışlardır. Bunların bir kısmı az bir müntesip kitlesiyle varlıklarını hicri V. asra kadar devam ettirmişlerse de, mezhep merkezli dönem olarak bilinen taklit döneminden itibaren, mutlak içtihat kapısının kapandığı düşüncesi ve kitlelerin, doğrudan veya dolaylı olarak dört mezhebe teveccühleri sebebiyle tarih sahnesinden çekilmek durumunda kalmıştır. Bu çalışmamızda, günümüzde yaşamayan sünnî fikıh mezhepleri hangileri olduğu klasik ve modern çalışmalardan istifade edilerek tespit edilmeye çalışılacak ve Fuat Sezgin' in Tarihu 't-Turâsi 'l-Arabî (GAS) adlı eserindeki tasnifiyle kıyaslanacaktır.

Anahtar Kelimeler: Mezhep, İslam hukuk mezhepleri, yaşamayan mezhepler, Fuat Sezgin.

* Dr. Öğr. Üyesi, Kocaeli Üniversitesi İlahiyat Fakültesi Fıkıh Anabilim Dalı, Kocaeli/Türkiye, huseyin.okur@kocaeli.edu.tr, orcid.org/0000-0003-4285-7478 


\title{
Sunni Schools of Fiqh in the History of Islamic Law That No Longer Exist and Fuat Sezgin's Classification
}

\begin{abstract}
Between the 2nd and 4th centuries after hijrah, during the period in the history Islamic law known as the time of mujtahid scholars, there have been Sunni madhhabs other than the four schools of fiqh known today. Almost all of these madhhabs (sects), which have reached numbers as high as several dozen at that time, have failed to maintain their existence and reach our time due to political and sociocultural factors. Although a small number of these schools have been able to continue their existence with small numbers of followers until the 5 th century after hijrah, from the period known as the madhhab-oriented imitation period, they began to withdraw from the stage of history due to the growth of the thought that absolute Islamic jurisprudence was no longer possible and due to the fact that masses of people had turned their favor towards the four madhhabs due to direct and indirect reasons. In this study, we will try to determine which madhhabs are the ones that have failed to maintain their existence by utilizing classical and modern works and comparing these findings to Fuat Sezgin's classification in his work titled Tarihu't-Turasi'l-Arabi (GAS).
\end{abstract}

Keywords: Madhhab (sects), sunni fiqh schools of Islamic law, discontinued madhhabs, Fuat Sezgin. 


\section{Giriş}

Tâbiîn döneminden itibaren İslam dünyasında fetva-kaza faaliyetlerinin yaygınlaşmasının ardından sonraki dönemde Irak, Hicaz, Suriye ve Mısır gibi merkezi bölgelerde yoğunlaşan içtihat faaliyeti, kurucu imamları ve öğrencilerinin çabalarıyla sistematik ve organize mezhepler haline bürünmüşler, bölgelerinde hukuk düşüncesinin gelişmesine katkıda bulunan otoriteler olmuşlardır. Tâbiîn döneminde görüş ayrılıklarının temelinde bulunan ehl-i hadis ve ehl-i rey ayrımı, müstakil müçtehitler döneminde mezheplerin ana omurgasını tanımlayıcı ana unsur haline gelmiştir. F1khî mezhepler temelde bu iki ayrıma dayanmakla birlikte hicri II. asırdan IV. asrın ortalarına kadarki süreç içerisinde pek çok fikhî mezhep ortaya çıkmıştır. Bu mezheplerin kahir ekseriyeti ehl-i sünnet mezhepleri olarak bilinmektedir. Fıkhî mezheplerin kuruluşuna etki eden faktörler kadar onların devamını sağlayan unsurlar da bu mezheplerin sürekliliğinde belirleyici rol oynamıştır. Bu faktör ve unsurlara sahip olmayan sünnî mezheplerin çoğu günümüze kadar ulaşmamıştır. Bu çalışmada kuruluş devrinden hicri IV. asrın ortalarına kadar "müstakil mezhep" olarak bilinen mezheplere değinilecek ve Fuat Sezgin'in tasnifi incelenecektir.

Fuat Sezgin'in ilgili tasnifine, Almanca orijinali Geschichte des arabischen Schrifttums (Leiden, 1967) olan ve Târîhu't-Turâsi'l-Arabî ismiyle Arapça'ya çevrilen eserini esas aldık. İslâm medeniyeti tarihinin başlangıcından itibaren naklî ve aklî ilimlere ait literatürünü konu edinen eserin ilk cildi Kur'an ilimleri, hadis, tarih, fikıh, kelâm, tasavvuf konularına ayrılmıştır. Birinci cildin üçüncü cüzü fıkıh bölümüne ayrılmıştır. Bir mukaddime ile başladığı bölümde ilk dönem fikıh yazıcılığının oluşumuna ve gelişimine, ayrıca bu döneme ait olduğu kaynaklarda belirtilen fıkıh eserlerine değinilmiştir. Emevî dönemine ait fikıh kitaplarını incelediği kısımda ise bu dönemin meşhur fakihlerinin hâl tercümelerine ardından da fikıhla ilgili çalışmalarına değinilmiştir. Abbasî dönemi fikıh çalışmaları için mütekaddimun dönemini temsil eden hicri 430'lu yıllara kadar değinilmiştir. Bu bölümde ilk olarak meşhur dört sünnî mezhep ele alınmıştır. Mezhep imamlarından başlayarak öğrencilerin ve mezhebi sonraki dönemlere taşıyan fakihlerin kısa hal tercümelerinden sonra onların eserlerine, şerh ve haşiyelerine ve bulundukları dünya kütüphanelerine yer verilmiştir. Sezgin Hanefî, Mâlikî, Şâfiî ve Hanbelî literatürünü inceledikten sonra, "Müstakil F1kıh Ekolleri" başlı̆̆ıyla günümüze ulaşmayan amelî mezheplerin literatürüne yer vermiştir. Sezgin'in tasnifinin özgün yanlarının olduğunu söyleyebiliriz. Özellikle konuyla ilgili ansiklopedi maddelerinde ve müstakil kitaplarda, çok bilinenler istisna tutulacak olursa; yaşamayan sünnî mezheplere yapılan atıfların doğrudan Sezgin'in eserine yapılıyor olması önemlidir. Bununla birlikte, Sezgin'in isimlerini zikret- 
tiği mezhepler ve bunlara ait literatür ile son dönem çalışmaları arasında farklar göze çarpmaktadır. Çalışmada yer yer bunlara işaret etmeye çalıştık.

\section{Mezheplerin Oluşumuna Tesiri Bakımından İçtihadın Mahiyeti}

İçtihat faaliyeti Hz. Peygamber, sahabe ve tâbiîn dönemlerinden itibaren var olmakla birlikte, tebe-i tâbiîn döneminden itibaren etkin ve sistematik bir şekilde uygulanmasıyla fikhî mezhepler oluşmaya başlamış. Tebe-i tâbiîn dönemi fakihleri, müslümanların karşılaşmış olduğu meseleler hakkında fikrî çalışmalar yapıp belli esaslar koymuşlardır. Fakat her bir fakihin beslendiği ilmî kaynağın farklı oluşu, hadislerin kabul kriterlerindeki kıstaslar, kıyasın delil değeri ve bölgenin örf ve âdetlerini dikkate almadaki ölçüler gibi hususlardan ötürü farklı içtihat ve usuller ortaya çıkmıştır. Mezheplerin teşekkülü döneminden önce de benzer görüş ayrılıklarından ve yöntem farklılıklarından söz etmek mümkündür ancak dönemin fakihleri arasında meydana gelen bu farklılaşma, 1stılahî anlamda mezhepleşmeyi gerektirecek seviyede olmamıştır. Örneğin, tâbiîn devri Mekke fikıh mektebinin meşhur temsilcisi Atâ b. Ebî Rebâh (ö. 114/732) hakkında "Atâ Mezhebi" ya da Medine fakihleri topluluğunu ifade etmek için "Medine Fakihleri'nin Mezhebi" gibi ifadeler kullanılsa da, bu daha ziyade ehl-i rey ve ehl-i hadis ayrımını, sınırlı görüş ve fetvalarda farklı beyanda bulunmalarını ifade etmek üzere kullanılmıştır. Zira bu dönemlerde kural ve usulleri belirginleşmiş ve sistemleşmiş bir usul ve kurumsallaşmış bir mezhep anlayışından söz etmek mümkün değildir. Bunun yanında tebe-i tâiîn döneminde, sistematik hale gelip ortaya çıkan mezhepleşmeyi de geçmiş birikimden ayrı görmek doğru değildir. Çünkü müçtehit imamlar dönemi, bir önceki kuşakta ana eğilimler etrafında başlayan ekolleşmelerin, bu dönemde yine aynı ekoller içerisinden şahıs merkezli yeni bir hukukî yapılanmaya evrilmiştir. İslam fetihlerinin gün geçtikçe ilerlemesiyle birlikte hususî bir iradeyle kurulan ya da farklı bir mahiyete büründürülen şehirler (emsâr) imar edilmiş, büyük ilmî ve siyasi merkezler kurulmuştur. Mekke, Medine, Küfe, Basra, Şam ve Misır bunların ön önemlileridir. Zira bundan sonra bu şehirlerde toplanan ve temsil kabiliyeti bulunan ulema (fukahâü'l-emsâr) ismiyle maruf fakih toplulukları oluşturarak içtihat faaliyetlerini hızlandırmışlardır. Medine'de Mâlik b. Enes (ö. 179/795), Mekke'de Muhammed b. İdrîs eş-Şâfiî (ö. 204/820), Şam'da Evzâî (ö. 157/774), Irak'ta Ebû Hanife (ö. 150/767) ile Süfyân es-Sevrî (ö. 161/778), Misır'da Leys b. Sa'd (ö. 175/791) ile ikinci merhalede Ahmed b. Hanbel (ö. 241/855) ile Davud ez-Zâhirî (ö. 270/884) bu bapta anılmas1 gereken önemli isimlerdir. ${ }^{1}$

1 Bkz.: Nesâî, Ebû Abdurrahman Ahmed el-Horasânî, Tesmiyettü Fukahâi'l-Emsâr, thk. Mahmud İbrahim Zayed, Halep, Dâru'l-Va‘y, 1369, s. 39; İbn Hazm, Ebû Muhammed Ali, el-İh- 
İçtihat faaliyetinin gelişen bu seyri ile içtihatta bulunan fakihlerin sergilediği farklı kudret ve kabiliyetten dolayı, çeşitli asırlarda derecelere ayrılmasına ya da böyle kabul görmesine sebep olmuştur. İçtihat faaliyeti, içtihat yapan fakihin içtihattaki kudretine bağlı olarak iki kısma ayrılmıştır ve esasında bu ayrım, içtihatta bulunan fakihin müstakil olup olmadığını belirleyen bir kriter olmuştur: İçtihadı bu açıdan mutlak içtihat ve mezhepte içtihat olarak iki ana gruba ayırmak mümkündür.

1. Mutlak içtihat. Bu hiçbir mezhebin prensiplerine bağlı olmaksızın müçtehidin kendi oluşturduğu istinbat yöntemleriyle elde edilen sistemin bütünüdür. Bu manada elde edilen içtihat kâmil içtihattır. ${ }^{2}$

2. Mezhep kurucusu müçtehitlerin ortaya koydukları prensiplere göre meseleleri tatbik etmede uygulanan içtihat yöntemidir. Buna tahriç veya mezhepte, meselede içtihat adı verilir. ${ }^{3}$

Hicri II. asırdan ibaren III. asrın sonlarına kadar olan dönem, kurucu mezhep imamlarının ortaya çıktığı dönemdir. Bu dönemden sonra da mutlak müçtehitler kategorisinde fakihler yetişmişse de ileride zikredeceğimiz bazı sebeplerden ötürü ve daha sonraları ortaya çıkan mezhep içi hiyerarşik sistemin belirlenmesi sebebiyle onların mutlak müçtehit oldukları pek benimsenmemiştir. Zira mezheplerin teşekkülünün ardından kurumsallaşan mezhep anlayışıyla birlikte içtihat faaliyeti içe dönük bir yapıya bürünerek daha dar bir kapsamda tahriç ve tercih çalışmalarına dönüşmüştür. Bu durum senkronik (eşzamanlı) ve diyakronik (artzamanlı) bir biçimde, mezhep içinde fakihler hiyerarşisinin oluşmasına ve buna bağlı olarak çeşitli ıstılahların gelişmesine de zemin hazırlamıştır.

Kurucu imalardan sonra gelen fakihlerin içtihat faaliyetlerine meselede içtihat, tahric veya tercih gibi isimlendirmeler verilmesi sebebiyle hicri IV. asırdan sonraki içtihat faaliyetlerine mutlak içtihat nazarıyla bakılmamıştır. Zira içtihat ameliyesinin tahriç, tercih ve meselede içtihat gibi fakihlerin sınıflandırmaya yarayan bir kategorizasyona tabi tutulması, içtihat faaliyetlerine bu gözle bakılmasına sebep olmuştur. Bunun bir örneği Şeyhülislam İbn Kemal Paşa’nın yaptığ fakihler hiyerarşisi çalışmasıdır. Bu sınıflandırmaya göre fakihler şu tabakalara ayrılmıştır:

kâm fî Usûli'l-Ahkâm, thk. Ahmed Muhammed Şakir, Beyrut, Dâru'l-Afâki'l-Cedide, t.y. II, s. 128.

2 Muhammed Ebu Zehra, Târîhu'l-Mezâhibi'l-İslâmiyye, Kahire, Dâru'l-Fikri'l-Arabi, t.y. s. 314.

3 Muhammed Ebu Zehra, Târîhu'l-Mezâhibi'l-İslâmiyye, s. 314. 
1) Dinde müçtehit olanlar: Dört mezhep imamı bu kategoridedir. Usûl ve füruda kimseyi taklit etmeyen, istinbat kaidelerini tesis eden ve bu kaidelerle doğrudan Kur'an, sünnet, icma ve kıyastan fürû hükümler çıkaran kimselerdir.

2) Mezhepte müçtehit olanlar: Ebû Yûsuf (v. 182/798), Muhammed (v. 189/805) gibi Ebû Hanife'nin (v. 150/767) öğrencileri bu tabakada yer alır. Bu kimseler hocalarının tespit ettiği kural ve kaideler muktezasınca edille-i erbaadan hüküm çıkarabilirler.

3) Meselede müçtehit olanlar (mukayyed müçtehit): Mezhep kurucusundan hiçbir rivayetin nakledilmediği meselelerde ictihad eden kimselerdir. Bunlar usûl ve fürûda mezhep imamina muhalefet edemezler. Ancak mezhep imamlarınca belirlenmiş usul ve kaidelere bağlı kalarak, hakkında nass olmayan meselelerde hüküm istinbatında bulunabilirler.

4. Tahriç ehli olanlar: İbn Kemal'e göre bu tabakada olanlar taklit ehlidirler. Onlar katiyen ictihad edemezler. Fakat usule iyi vakıf olmaları ve kaynakları bilmelerinden ötürü mezhep imamından ve onun müçtehit talebelerinden nakledilen iki yönlü ve mücmel bir sözü, iki duruma ihtimali bulunan kapalı bir hükmü, fürûdaki kaidelere ve benzerlerine bakarak açıklayabilirler.

5. Tercih ehli olanlar: Bunlar da taklit ehlidirler. Bu tabakada olanlar, "Bu daha evla", "Bu rivayetler içinde en sahih olanı", "Bu daha açık", "Bu kıyasa daha uygun" gibi sözleriyle rivayetler arasında tercihte bulunurlar.

6. Temyiz ehli olanlar: Bu sınıfta yer alan fakihler iki kuvvetli görüş arasında daha kuvvetli olanı ayırabilen mukallit fakihlerdir.

7. Mukallitler: İbn Kemal'e göre bunlar yukarıda belirtilenleri yapamayan kimselerdir. ${ }^{4}$

İlk nüveleri kendisi tarafından atılmasa da İbn-i Kemal tarafından yapılan fukahayı sınıflara ayırma çalışması, genelde kabul görmüştür. Ondan sonra da birçok eserde aynen veya özet şeklinde iktibas edilmiştir. Bu tasnifi benimseyen âlimlere Kınalızâde (v. 1561) , Taşköprüzâde (v. 1584) ${ }^{6}$ ve İbn Âbidîn'i (v. 1252/1836) $)^{7}$ örnek verebiliriz.

4 Kemâl Paşazâde Şemseddîn Ahmed b. Süleymân, Tabakâtü'l-Fukaha, Ankara, Milli Kütüphane, 01 Hk 467/1. Ayrıca bkz. Hasan Özer, “İbn Kemal ve Tabakatü’l-Fukaha Adlı Eseri (tahkikli neşir)", İslam Hukuku Araştırmaları Dergisi, Konya, 2009, sayı 14, s. 353-374.

5 Kinalızade, Alaeddin Ali b. Emrullah, Muhtasar fi Zikri Tabakati'l-Hanefiyye, Köprülü Yazma Eser Kütüphanesi, Hafız Ahmed Paşa Koleksiyonu, 34 Ha 330/15.

6 Taşköprizâde Ahmed Efendi, Tabakâtü'l-Fukaha, nşr. Ahmed Nîle, Musul, 1961, s. 7-11.

7 İbn Âbidîn, Muhammed Emin, Şerhu'l-Manzûmeti Ukûdi Resmi 'l-Müftî, Haydarabad, 2000, s. 2-3. 
İbn Kemal'in fikhî istidlâl kategorilerini çoğaltmak suretiyle yaptığı fakihler tasnifi, her sınıfa giren âlimlerin kategorik kavramlarının birbirinden ayrilması ve her kategoriye dair verdiği örneklerler bakımından tenkitler almıştır. Ebû Zehra bu ayrımın tenkitçilerinden biridir. Ona göre, Hanefî mezhebinde, rivayetlerin çokluğundan mütevellit karmaşanın engellenmesi için tercih ehli gibi bir sınıfın olması elzem olmakla birlikte, benimsenen fukaha tabakatı içinde, tercih ehli fakihlerin yeri isabetli değildir. Ebû Zehra'nın kanaatine göre, tahriç ehli ile tercih ehli arasındaki fark da açık değildir. Kısımlar birbirine karışmadan taksimin doğru olabilmesi için üçüncü, dördüncü ve beşinci tabakalardan birini kaldırmak gerekmektedir. Bunlar iki tabaka hâline indirilebilir. Biri tahriç ehli tabakası olup bunlar mezhep imamlarından bir hüküm naklolunmayan meseleler hakkında, mezhebin kaidelerine göre hüküm çıkaran fukahadır. Diğeri ise tercih ehli tabakası olup bunlar da muhtelif görüş ve muhtelif rivayetler arasında tercih yapıp en kuvvetli, en sahih olanları beyan eden ve kıyasa muvafık olup halkın maslahatına uygun olanını seçen kimselerdir. ${ }^{8}$

İbn Kemal'in fakihler hiyerarşisi tasnifini eleştirenlerden biri de Leknevî'dir (1848-1886). Ona göre müçtehit iki kısma ayrılır. Birincisi mutlak müçtehittir ki o fıkıhta tam bir melekeye sahip, basiretli, delillerden hüküm istinbatına liyakatli ve buna gücü yeten Ebû Hanife, Mâlik, Şâfiî, Ahmed, Ebû Yusuf, Muhammed, Züfer, Sevrî, Evzâî ve İbn Ebî Leylâ gibi kimselerdir. İkincisi ise, belli (muayyen) bir mezhepte müçtehit olanlardır. Bunlar da, mezhebinin imamının usulünü, delillerini kavrayabilen, usul yönünden nasları esas alarak onlardan füru hükümleri istinbat edebilen kimselerdir. Bunlar her ne kadar mutlak ictihad derecesine ulaşamamış olsalar da mukallit de değillerdir. Bilakis bunlar, usulde basiret sahibi, istidlal ehli, mezhep teorilerini kavramış, fikıhta derin kavrayış sahibi kişilerdir. Onlar fakîhü'n-nefs olup ilimde yüksek bir mevkiye erişmişlerdir. Cerh ve tadil noktasında yeterli donanıma sahip olup sahih olan ile zayıf arasında temyiz yapabilecek kabiliyettedirler. Bu gibi kimseler meseleleri yeri geldiğinde özetleyip (telhis) yeri geldikçe izah etmeye (bast), hüccetleri takrir etmeye, şüpheli delilleri ayıklamaya muktedirdirler. Fetva verip tahric yapabilirler. Bunlar tüm konular hakkında olmasa da bazı meselelerde müçtehittirler (müctehid fi'l-mesele). Hüküm istinbatında müstakil değillerdir; bütün bu hususlarda, hüküm istinbat esaslarında ve delillerin tayininde (tercihu'l-edille), imamlarının beyanlarına ihtiyaç duyarlar. ${ }^{9}$

8 Muhammed b. Ahmed b. Mustafa Muhammed Ebû Zehre, Eb̂̂ Hanîfe Hayatuhu ve Asruhu Ârâuhu ve Fıkhuhu, Misır, Dâru'l-Fikri'l-Arabi, t.y., s. 501.

9 Leknevî, Abdülhay, en-Nâfiu'l-Kebîr limen Yutâli ‘ el-Câmiu’s-Sagîr, I, 1. bs., Beyrut, Alemu'l-Kutub, 1986, s. 7-8. 
Fukaha tabakatını bu iki temel taksimden ibaret gören Leknevî’ye göre, bundan sonra gelenlerin herhangi bir hiyerarşik sıralamaya tabi tutulmaması gerekir. Ona göre, mezhebin birinci tabakası belli olmakla birlikte ikinci kategoride herkes olabilir. Bu sebeple Leknevî ikinci tabakaya dair herhangi bir isim zikretmemiştir. Yukarıda zikrettiği şartları taşıyan herkes bazı meselelerde ictihad ameliyesinde bulunabilir. Mutlak ve meselede müçtehit ayrımı yaptıktan sonra Leknevî bunların dışında kalanların ancak fikhî dirayet ve rivayet yönünden zayıf ya da kuvvetli (sika) olarak tarif edilebileceğini kaydeder. Fukaha tabakalarını her hangi bir zaman dilimine tahsis etmek de isabetli bir düşünce değildir. Ona göre tabakat tasnifinden gaye, tabakalarda zikredilen sifatlara sahip kimselerin özellikleridir. Yoksa bununla belirli bir zamanda yaşamış fakihler kastedilmemiştir. Hatta klasik dönemde yaşamış pek çok fakih, mukallit derecesindedir ve hüküm istinbatında bulunamayacak derecede fikhî yeterlilikten yoksundur. Bunun yanında klasik dönem sonrasında yaşayıp ictihad derecesine ulaşmış pek çok fakihin varlığı da malumdur. ${ }^{10}$

Tabakalar arası ayrımın net olmaması ve bu tabakalarla ilgili fukaha tavsiflerinin ciddi tenkitlere maruz kalması sebebiyle son dönemde telif edilen eserlerde böyle bir tasniften vazgeçilmiştir. Sezgin'in müstakil mezhep sahiplerini zikrederken de görüleceği üzere, bazı fakihlerin müstakil olup olmadığ 1 hakkındaki ihtilaflar da bu tür bir tartışmanın ürünüdür. Yani bir fakihin müstakil bir mezhep imamı mı yoksa bir mezhebe mi bağlı olarak mı içtihat ettiği fıkıh tarihi araştırmalarında tartışma konusu olmuştur.

\section{Mezhebin Teșekkülünü Sağlayan Âmiller}

Bir fıkıh mezhebinin kısa sürede teşekkül etmediği bir gerçektir. Çünkü fıkha dair görüşler bütününün birey ve toplum tarafından benimsenmesi, tutarlılı̆̆ının test edilmesi, güvenilerek onlara bağlanılması, onlarla amel edilmesi, başkalarına karşı savunulması, taraftarların oluşması, terimlerin yerleşmesi ve görüşlerin kitaplarda yazılı hale getirilmesi uzunca bir süreç almaktadır. Üstelik mezhebin teşekkülü, sürekliliğiyle doğru orantılıdır.

Bir mezhebin teşekkül edebilmesi veya etmiş sayılması için, görüşleri etrafinda toplanılan ve otorite kabul edilen bir imamın, ona ait usulün ve bu usule uygun füru-1 fikh hükümlerinin, o ekole ait terimlerin, tanımların, özel kavramların, mezhebi temsil eden âlimlerin ortaya çıkması, taraftar kitlenin oluşması, görüşlerin yazıya geçirilip muhaliflere karşı savunulması gibi âmillerin mevcut olması gerekir. Bu, bütün mezhepler için teşekkülün ortak özellikleridir. 
Mezheplerin gelişmesi, daha ziyade imamların yetiştirdikleri öğrenciler ve müntesipler sayesinde gerçekleşmiştir. Özellikle mezheplerin kitleler tarafından benimsenmesi, onların yayılması açısından büyük önem arz etmiştir. Bu sebeple öğrencisi olmasına rağmen müntesibi bulunmayan ya da müntesipleri tarafından yayılmayan mezhepler kısa zaman içinde yok olup gitmiştir.

Mezheplerin yayılmasına etki eden faktörlerden biri de siyasi destektir. Dönemin İslam beldelerinde hâkim olan siyasi otorite tarafından atanan kadılar ve onların siyasetçilerin benimsediği mezhebe göre fetva vermeleri, atanan kadının bir mesele hakkında fetva verirken kendi mezhebinin görüşleri çerçevesinde hareket etmesi, mezhebin görüşlerinin yaygınlık kazanmasına vesile olan bileşenler arasında sayılmaktadır. Örneğin Hârûn er-Reşîd devrinden itibaren ihdas edilen kâdılkudâtlık (başkadıl1k) müessesesine ilk olarak İmam Ebû Yûsuf'un getirilmesi sebebiyle, ${ }^{11}$ bu tarihten sonra tayin edilen kadılar genellikle Hanefî mezhebinden seçilmiştir, denilebilir. ${ }^{12}$ Keza Endülüs’te Kurtuba emirinin kadı atama konusunda Yahya b. Yahya el-Mesmûdî’ye (ö. 234/849) danışması ve onun da kendi talebelerini yönlendirmesi, bu bölgede Mâlikî mezhebinin görüşlerinin yayılmasında etkili olmuştur. ${ }^{13}$ Mâlikî mezhebinin Medine'de ortaya çıkmasına rağmen, günümüzde Hicaz'da etkili olamamasının nedenleri arasında, zikrettiğimiz bu faktörlerin etkisinin olduğu büyüktür. Aynı şekilde Irak bölgesinde atanan kadıların genellikle Hanefî ve Şâfiî mezhebine mensup olmaları, Mâlikî ve Hanbelî mezheplerinin bu bölgede zayıflamasına neden olmuştur. Yine Büyük Selçukluların Hanefî mezhebini benimsemeleri, Anadolu, Irak ve Suriye'de Şâfî̂ mezhebinin etkisinin azalmasına neden olmuştur. Bunun örnekleri çoğaltılabilir.

Fakat mezheplerin etkin bir biçimde coğrafi dağılımlarının sadece siyasi sebeplere hamledilmesi de doğru olmaz. Zira hiçbir mezhep kurucusunun vefatıyla tekâmül etmemiş, öğrencilerinin görüşleri ve mezhebe katkılarıyla tamamlanmıştır. Bu sebeple mezhebin oluşmasında siyasi sebepler kadar, mezhep görüşlerini oluşturan fakihlerin ve müntesiplerinin sosyo-kültürel durumları da etkili olmuştur. Örneğin Zehebî (ö. 748/1348), kendi zamanında mezheplere tabi olmanın coğrafi etkileriyle ilgili olarak, "Günümüzde Mağrib'de bir kişi Hanefî̀ mezhebine tabi olmayı istese bu ona çok ağır gelir; Ahmed b. Hanbel'in

11 Zehebî, Şemseddin Muhammed, Târîhu'l-İslâm ve Vefeyâtü'l-Meşâhîri ve'l- 'Alâm, thk. Ömer Abdüsselam Tedmürî, XII, Beyrut, Dâru'l-Kitâbu'l-Arabî, 1993, s. 501.

12 Abdülvehhab Hallâf, 'İlmu Usûli’l-Fıkh ve Hulâsatu Târîhu't-Teşri', I, Mısır, Matbaatü'l-Medenî, t.y., s. 256.

13 Zehebî, Şemseddin Muhammed, Siyeru 'Alâmi'n-Nübelâ, VIII, Kahire, Dâru'l-Hadîs, 2006, s. 517. 
mezhebi de öyle..."14 demek suretiyle mezheplerin kitleler tarafından kabulünün kültür ve sosyal yaşantıyla da ilgili olduğunun altını çizmiştir.

\section{Mezheplerin Yaşamamasının Önemli Nedenleri}

Özetle ifade etmek gerekirse; mezheplerin tutunması, yerleşmesi ve yayılmasının siyasi, içtimai, iktisadî, medeni bazı âmilleri vardır. Sünnî fikıh mezheplerinin tamamının günümüze kadar ulaşmamasının sebeplerinin bazılarını şöyle sıralayabiliriz:

1. Mezhep imamları ya da öğrencileri ve tabileri, günümüze ulaşan mezheplerde olduğu gibi mezhep usullerini tedvin etmemişlerdir.

2. Bu mezheplere ait bilgiler tedvin edilmiş olmasına rağmen mezhep imamının veya önde gelen talebelerinin yaşamlarını yitirmesinden sonra tedvin ve istinsah faaliyeti devam etmemiş, sonraki nesillere de aktarılmamıştır.

3. Günümüze ulaşmayan mezheplerin görüşlerini alıp başka coğrafyalara taşıyacak, geliştirecek ve insanlar arasında yaşatacak öğrencilerinin olmaması.$^{15}$

4. Mezhep görüşleri dönemin siyasi otoritesi tarafından himaye edilmemiş olmasi.

5. Mezheplerin bulundukları coğrafyanın kültürel ve sosyal yapısına uygun olmamas1.

6. Bu mezheplerin çoğunluk görüşlerinin diğer mezheplerin görüşlerine benzemesi.

7. Bu mezheplerin özellikle Şâfiî, Mâlikî ve Hanbelî mezheplerine olan görüş benzerliği sebebiyle, halk kitleleri arasında münazara ortamı bulamaması ve zamanla popülerliğini yitirmesi.

8. Bu mezheplerin fikhın her alanında görüş serdedemeyişi dolayısıyla insanlara alternatif seçenekler sunamamas1.

9. Mezhebe ait metin ve muhtasar eserlerin kaleme alınmayış1 ve çoğu görüşlerin şifahi olarak nakledilmesi; ders halkası şeklinde yürümesi.

10. Mezhep görüşlerinin fikhın her sahasını kuşatmaktan ziyade tekil mevzularla ilişkili olmas $1{ }^{16}$ ve kümülatif bir doktrin haline gelmemesi.

14 Zehebî, Siyeru 'Alâmi'n-Nübelâ, VIII, s. 91.

15 Şaban Muhammed İsmail, el-Medhal li Dirâseti'l-Kur'ân ve 's-Sünnet ve'l-Ulûmi'l-İslamiyye, II, Halep, Dâru'l-Ensar, t.y., s. 381.

16 Şaban, el-Medhal li Dirâseti'l-Kur'ân ve's-Sünnet, II, s. 381. 
Tarihte belli bir müddet yaşamış ancak daha sonraları yukarıda zikrettiğimiz sebeplerden ötürü ömrünü tamamlamış sünnî mezhepler, ya tamamen ortadan kaybolmuş ya da kitlesi daha büyük olan mezheplerin altında mütalaa edilmek zorunda kalmıştır. Eserinde meşhur fakihlerin mezheplerinin durumlarını inceleyen müteahhirûn dönemi Şâfî̀ hukukçulardan Ebu'l-Hasan el-Kerecî'ye göre bu mezhepler farklı sebeplerden ötürü diğer mezheplerin çatısı altında kaybolmuştur. ${ }^{17}$ Örneğin Süfyân b. 'Uyeyne (ö. 198/814), tercih ettiği hükümleri tasnif etmeyip ashabı olan Şâfî̂ ve Ahmed b. Hanbel'in mezhebinin görüşlerini tasnif etmiştir. Bu sebeple vefatından sonra mezhebi ve görüşleri bu iki mezhebin içinde kaybolmuştur. ${ }^{18}$

Misır fakihi Leys b. Sad'ın (ö. 175/791) talebeleri onun mezhebini tasnif etmekle meşgul olmamıştır. Hatta İmam Şâfî̀’nin bu durum hakkında "Leys, Mâlik'ten daha fakihtir; ancak ashabı onun mezhebini tedvin etmemiştir." dediği nakledilir. Leys'in mezhebi tedvin edilmediği ve görüşleri Mâlik ve Sevrî’ye yakın olduğu için bu iki mezhebin altında kaybolmuştur. ${ }^{19}$

Kerecî’nin ifadelerine göre Evzâî mezhebi ise fikhın hemen hemen her alanında görüşleri bulunan bir mezhep olmasına rağmen mezhep görüşleri kısmen Mâlik, Şâfiî ve Sevrî’ye mutabık olduğu için onların görüşleri arasında kaybolmuştur. İshâk'ın mezhebi de aynı sebepten ötürü Ahmed b. Hanbel'in görüssleri arasında kaybolmuştur. ${ }^{20}$

\section{Yaşamayan Mezhep Tasnifleri}

İslam mezhepler tarihi çalışmalarında yapılan mezhep tasnifleri ve mezheplerin doğuşuna etki eden faktörler daha ziyade itikadî mezhepler cihetinde yapılmış, fikhî mezheplerin kelamî mezhepler kadar çok ve belirgin olmaması ve birkaçı (Zeydiyye, İmamiyye İsnâaşeriyye, İbâdiyye vb.) müstesna, geneli "ehl-i sünnet mezhebi” çerçevesinde mütalaa edilmesi sebebiyle ${ }^{21}$ kelamî mezhepler kadar araştırmaya konu olmamıştır. Ayrıca bir fakihe nispet edilen müstakil bir mezhebin varlığını tespit etmenin zorluğu da bu yönde etkili olmuştur.

17 Kerecî bu nakillerini Ebu Hamid İsferâyinî’nin Talikat isimli eserine atıfta bulunarak nakleder. Elli cildi aşkın olan bu eser günümüze ulaşamamıştır.

18 Ebu Hasan el-Kerecî, el-Fusûl fi'l-Usûl ani'l-Eimmeti'l-Fuhûl, thk. Salih b. Abdülaziz es-Sindî, Beyrut, Dâru'l-Lü'lü, t.y., s. 18.

19 Ebu Hasan el-Kerecî, el-Fusûl fi'l-Usûl, s. 18.

20 Ebu Hasan el-Kerecî, el-Fusûl fi'l-Usûl, s. 18.

21 Şaban Muhammed İsmail, el-Medhal li Dirâseti'l-Kur'ân, II, s. 384. 
Ayrıca bir mezhebin müstakil mezhep sayılabilmesi için, sahip olduğu usulün özgünlük sınırlarının belli olmaması ve herkesin üzerinde ittifak ettiği ayırt edici kriterlerin bulunmaması, müstakil mezheplerin sayısının tespitini zorlaştırmıştır. Öyle ki bir fakihin, bir mesele hakkında görüş ayrıllı̆̆ını, müstakil mezhep kriteri saydığımızda, sayısız mezhep ve mezhep isminin ortaya çıkması gibi sakıncalı bir sonucun doğacağı ortadadır. Esasen tabakat ve usul kitaplarındaki müstakil mezhep sayısının belirsiz oluşu da, bu mezheplere ait bilgilerin yetersiz oluşuna bağlı olarak geçmişe dönük müstakil mezhep tespiti yapmanın imkânsızlığından kaynaklanmaktadır.

İslam hukuk tarihi araştırmalarına dair yazılan eserlerde, günümüze ulaşmayan fikhî mezhepler için "el-mezâhibu'l-münderise"22, "el-mezâhibu'l-mündesira"23 "el-mezâhibu'l-munkariza"24 veya "el-mezâhibu'l-bâide"25 yani eseri, izi kalmamış, mevcut olmayan şeklinde kullanımlar mevcuttur. Ayrıca bu mezheplere, kitlelere mal olmadığ 1 ve kurucularının vefatlarıyla birlikte yok oldukları için kişisel mezhep anlamında "el-mezâhib-i ferdiyye" de denilmiştir. Bazı modern çalışmalarda bu mezhepler için "el-mezâhibu'l-müdevvene" 26 tabiri kullanılmıştır. Ancak buradaki tedvini, mezhep kural ve usullerinin yazıldığ 1 eserleri bulunan anlamında değil de sistemleşme anlamında düşünmek daha yerinde olacaktır.

Ülkemizde ise bu tür mezhepler için daha ziyade "yaşamayan mezhepler" şekliyle bir ifade kullanılmaktadır. Yani taraftarlarıyla belli coğrafyalarda hâlâ insanların dinî ve hukukî hayatını sürdürmelerini sağlıyorsa ona "yaşayan mezhep", görüşleri sadece kitaplarda ve literatürde tekrar ediliyor fakat dikkate değer taraftar kitlesi kalmamış olanlara da "yaşamayan mezhep" denilmiştir. Mezhep, bir konuda sistematik usullerle ortaya konulan görüş ve yaklaşım bütünü olarak tanımlanırsa, mensubu kalmasa da, kitaplarda doğru bir şekilde bize aktarılan mezheplerin de bir anlamda varlığını devam ettirdiği söylenebi-

22 Abdülkerim Zeydan, el-Vecîz fì Usûli'l-Fılkh, Beyrut, Müessesetü Kurtuba, 1987, s. 412.

23 Muhammed Mustafa eş-Şelebî, el-Medhal fi 't-Ta 'rîfi bi 'l-Fıkhi'l-İslâmî, Misır, Dâru't-Te'lîf, 1962, s. 129.

24 Muhammed Mustafa ez-Zuhayli, el-Vecîz fì Usûli'l-Fıkhi'l-İslâmî, II, Dımaşk, Dâru'l-Hayr, 2006, s. 371.

25 Muhammed Hudari Beg, Târîhu't-Teşrîi'l-İslâmî, Beyrut, Dâru'l-Kütübi'l-İlmiyye, 2018, s.178; İbnü'l-Cellâb, Ebu'l-Kâsım Ubeydullah, et-Tefri', thk. Hüseyin b. Salih el-Hemedânî, I, Beyrut, Dâru'l-Garbi'l-İslâmî, 1987, s. 73.

26 Bu tabiri Hacevî, el-Fikru's-Sâmî adlı eserinde ilk dönem sünni fikıh mezheplerini ifade etmek için kullanmıştır. Bkz. Muhammed b. Hasan b. Arabi es-Sealibi Hacvi, el-Fikru's-Sâmî fî Târîhi Fıkhi'l-İslâmî, Beyrut, Dâru'l-Kütübi'l-İlmiyye, 1995, s. 17. Ayrıca bkz.: Ebu Yahya Zeynüddin Zekeriyya el-Ensârî, Esnâ 'l-Metâlib fî Şerhi Ravzi 't-Tâlib, thk. Muhammed Tamir, IV, Beyrut, Dâru'l-Kütübi'l-İlmiyye, 2000, s. 286. 
lir. Ancak gerçek şu ki, bir mezhebin yaşadığını gösteren en önemli unsur, onun taraftarlarının olmasidır.

Klasik dönemde mezhep içinde müçtehit sayılanlar pek çok olmasına rağmen kast ettiğimiz anlamda bir mezhep kurucusu ve mutlak müçtehit olarak kabul edilenlerin sayısı esasında çok fazla değildir. Gerçi bazı günümüz çalışmalarında bu sayının yüzlerce olduğu ifade edilse de bu rakam abartıdan öteye geçmemektedir. ${ }^{27} \mathrm{Bu}$ karmaşanın temelinde kendisine tâbi olunan fakih ile mezhep sahibi fakih ayrımının belirgin olmamasıdır. Bu sebeple sahabenin her birini müstakil bir müçtehit gibi görenlerin yanında onlardan sadece müçtehit olanları "müstakil müçtehit" olacağını savununlar da olmuştur. Suyûtî bu ayrımı belirginleştirme sadedinde müçtehit ile mezhep imamı ayrımına gitme yolunu tercih eder. Ona göre İslam milleti içindeki mezheplerin sayısı dört ile sınırlı olmadığı gibi müçtehitler de sayılamayacak kadar çoktur. Hatta İslam'ın ilk dönemlerinden itibaren herkesin sahabe, tâbiîn ve tebe-i tâbiînden tâbi olduğu bir fakih yani mezhebi bulunmaktaydı. Tebe-i tâbiîn döneminden itibaren ise taklit edilen ve görüşleri tedvin edilmiş olan on kadar mezhep bulunmaktaydı. Bunlar dört meşhur fikıh mezhebi ile Süfyân es-Sevrî, Evzâî, Leys b. Sa'd, İshâk b. Râhûye, İbn Cerîr et-Taberî ve Davud ez-Zâhirî mezhepleriydi. Bu mezheplerin her birinin müntesipleri vardı. Zamanında mezhep görüşleri ve fetvaları tatbik edilirdi. Fakat bu mezheplerin kurucularının vefat etmesinin akabinde, yaklaşık hicri 500'lü yıllarda müntesiplerinin yeterli ihtimamı göstermemesi sebebiyle tarih sahnesinden silindi." 28

Zehebî de Suyûtî gibi benzer bir tasnife gider. Ona göre fakihler topluluğu içinde tâbileri bulunanlar olduğu gibi bulunmayanlar da vardır. Resûlullah'ın sahabelerinden fakih olanlar kendilerine tâbi olunanlardandır. Bundan sonraki dönemde tâbiîn fakihlerinden Alkame b. Kays (ö. 62/682), Mesrûk b. el-Ecda ‘ (ö. 63/683 [?]), Abîde es-Selmânî (ö. 72/691), Saîd b. el-Müseyyeb (ö. 94/713), Ebü'ş-Şa'sâ Câbir b. Zeyd (ö. 93/711-12), Saîd b. Cübeyr (ö. 94/713 [?]), Ubey-

27 Frideric Carn, Ihtilâfu'l-Fukahâ (Mukaddime kısmı), Beyrut, Dârul'l-Kütübi'l-İlmiyye, t.y., s. 16. George Makdisi, "İslam Hukuk Tarihinde Sünnî Mezheplerin Rolü” ismiyle çevrilen ve 10 Kasım 1977'de, Middle East Studies Derneği'nin New York'taki yıllık toplantısına başkanlık konuşması olarak sunduğu tebliğinde, Adam Mez'e atıf yaparak, hicri III. asırda yaklaşık beş yüz kadar hukuk ekolünün bulunduğu, hakkındaki söylemi, tarihi ve sosyolojik olarak mezheplerin oluşum ve kurumsallaşma şartlarına uygun bir varsayım olmadığı için abartılı bir yaklaşımdan ibarettir. Bkz.: George Makdisi, "İslam Hukuk Tarihinde Sünnî Mezheplerin Rolü”, Recep Tayyip Erdoğan Üniversitesi İlahiyat Fakültesi Dergisi, çev. Yakup Mahmutoğlu, 5, 2014, ss. 189-201.

28 Suyûtî, Celaleddin, el-Hâvî li'l-Fetâvî, thk. Abdüllatif Hasan, II, Beyrut, Dâru'l-Kütübi'l-İlmiyye, 2005, s. 148. 
dullah b. Abdullah (ö. 94/713 [?]), Urve (b. Zübeyr ö. 94/713), Kasım (b. Muhammed b. Ebî Bekr es-Sıddîk ö. 107/725 [?]), Şa 'bî (ö. 104/722), Hasan-1 Basrî (ö. 110/728), İbn Sîrîn (ö. 110/729), İbrahim en-Nehaî (ö. 96/714) gibileri tâbileri bulunan kimselerdendir. ${ }^{29}$

Ardından İbn Şihâb ez-Zührî (ö. 124/742), Ebû'z-Zinâd (ö. 130/748), Eyyüb es-Sahtiyânî (ö. 131/749), Rebîa (ö. 136/753 [?]) gibi bu ara dönemde yaşamış diğer bazı fakihler gelir. Sonra ise Ebû Hanîfe (ö. 150/767), Mâlik (ö. 179/795), Evzâî (ö. 157/774), İbn Cüreyc (ö. 150/767), Ma‘mer b. Râşid (ö. 153/770), İbn Ebî Arûbe (ö. 156/773), Süfyân es-Sevrî (ö. 161/778), Hammadeyn (Hammad b. Zeyd ile Hammad b. Seleme), Şu'be (b. el-Haccâc ö. 160/776), Leys b. Sa'd (ö. 175/791), İbn Mâcişûn (ö. 212/827) ve İbn Ebî Zi‘b (ö. 159/776) gibileri gelir. ${ }^{30}$

Abdullah b. Mübârek (ö. 181/797), Müslim ez-Zencî (Müslim b. Hâlid [179/795]), Kadı Ebû Yusuf (ö. 182/798), Hıkl b. Ziyâd'ın (v. 179/796), Veki ‘ (ö. 197/812), Velîd b. Müslim (ö. 195/810) tâbileri olan fakihlerdir. Yine Şâfî̂ (ö. 204/820), Ebû Ubeyd (ö. 224/838), Ahmed b. Hanbel (ö. 241/855), İshâk (b. Râhûye ö. 238/853), Ebû Sevr (ö. 240/854), Büveytî (Ebû Ya'kub ö. 231/846) ve Ebû Bekir b. Ebî Şeybe de (ö. 235/849) bunlardandır. ${ }^{31}$

Bu tabakadan sonra gelen Müzenî (İsmâîl b. Yahyâ ö. 264/878), Ebû Bekir el-Esrem (ö. 261/874-75 [?]), Buhârî (ö. 256/870), Davud b. Ali (Dâvûd ez-Zâhirî ö. 270/884), Muhammed b. Nasr el-Mervezî (ö. 294/906), İbrâhîm el-Harbî (ö. 285/899) ve İsmail el-Kâdî de (İsmâîl b. İshâk b. İsmâîl el-Ezdî el-Cehdamî ö. 282/896) böyledir. Yine Muhammed b. Cerîr et-Taberî (ö. 310/923), Ebû Bekr b. Huzeyme (Muhammed b. İshâk en-Nîsâbûrî ö. 311/924), Ebu'l-Abbas b. Süreyc (ö. 306/918), Ebû Bekir b. Münzir (ö. 318/930 [?]) (Münziriyye mezhebinin kurucusu), Ebû Cafer et-Tahâvî (ö. 321/933) ve Ebû Bekir el-Hallâl (ö. 311/923) müntesipleri bulunan müçtehitlerdendir." 32

Zehebî’ye göre sahabe, kendilerine yapılan isnadın sabit ve sahih olması kaydıyla, kendilerine tâbi olunan kimselerdi ve müçtehit idiler. Onlardan sonra gelen nesilde pek çok âlim-fakih olsa da bunlar daha ziyade yukarıda zikri geçenlere tâbi oluyorlardı. Zehebî, yukarıda zikri geçen bu isimlerin tamamı için mutlak müçtehit ifadesini kullanmamakla beraber bunların kendilerine tâbi olunan kimseler olduğunu ifade etmek suretiyle bu manayı ima etmiştir. Nitekim daha sonra

29 Zehebî, Şemseddin Muhammed, Siyeru 'Alâmi'n-Nübelâ, thk. Şuayb el-Arnavut, VIII, Beyrut, Müessesetü'r-Risale, 1985, s. 91.

30 Zehebî, Siyeru 'Alâmi'n-Nübelâ, VIII, s. 91.

31 Zehebî, Siyeru 'Alâmi'n-Nübelâ, VIII, s. 91.

32 Zehebî, Siyeru 'Alâmi'n-Nübelâ, VIII, s. 91. 
gelen cümlelerinden de bu anlaşılmaktadır: "Bundan sonraki dönemde ise içtihat faaliyeti azald ve muhtasar metinler yazılmaya başlandı. Fukaha kimin daha iyi bildiğine bakmadan, tazim gösterme kastı ile ve adetlere de teslim olarak ve bir de yöresel etkilerden ötürü taklide daldı. "33

Kaynaklarda başka mezheplerin olduğu da ifade edilmektedir. Örneğin Buhârî, Ebû Zür'a ed-Dımaşkî (ö. 281/894) ve İbn Ebî Hatim (ö. 327/938) bunlar arasında sayılmıştır. Ebû'l-Hasan el-Kerecî (ö. 539/1114), Ebû Zür'a ve Ebû Hatim' in bazı ibadetler fikhı alanında istinbatlarının bulunduğunu ancak bunların da Ahmed b. Hanbel'in mezhebine kısmen muvafik olması sebebiyle Hanbelî mezhebi altında mütalaa edilmesi gerektiğini söyler. Kerecî, Buhârî hakkında ise onun herhangi bir hüküm istinbatını görmediğini ifade etmekle birlikte bazı kimselerin onun bir takım tercihlerinin olduğunu söylediğini ve görüşlerinin İshâk ve Ahmed b. Hanbel'in görüşlerine muvafik olduğundan söz eder. ${ }^{34}$

Hukuk mezhepleri tasnifinde bulunan bir başka kişi de Şa 'rânî'dir (ö. 973/1565). O, mezhep sahibi olanları sahabe, tâbiîn ve tebe-i tâbiîn ayrımı yapmadan zikreder. Ona göre sahabeden Hz. Âişe (ö. 58/678), Abdullah İbn Ömer (ö. 73/692), Abdullah İbn Mes'ud (ö. 32/652-53); tâbiînden Atâ b. Ebî Rebâh (ö. 114/732) ve Mücâhid b. Cebr'in (ö. 103/721) fikıh mezhepleri bulunmaktaydi. Bundan sonraki dönemlerde yaşayan Ebû'l-Leys es-Semerkandî (ö. 373/983), Dâvûd ez-Zâhirî (ö. 270/884), Ebû Hanife, Mâlik b. Enes, Şâfîi, Ahmed b. Hanbel, Süfyân es-Sevrî, Süfyân b. 'Uyeyne, Muhammed b. Cerîr et-Taberî, Ömer b. Abdülaziz, A'meş (Süleymân b. Mihrân el-Kûfî ö. 148/765) Şa 'bî (Âmir b. Şerâhîl ö. 104/722) ve İshâk b. Râhûye de (ö. 238/853) mezhep sahibi kimselerdendir. ${ }^{35}$

Son dönemlerde yazılmış İslam hukuk tarihi çalışmalarında genellikle mezhep imamı oldukları kesin olarak bilinenlere yer verilmiştir. Bu alanda yazılmış en başarılı eserlerden birini sahibi olan Faslı âlimlerden Muhammed b. Hasan el-Hacvî (ö. 1956/1376) el-Fikru's-Sâmî fí Târîhi Fıkhi'l-İslâmî adlı eserinde günümüze ulaşmayan mezhepleri "tedvin edilmiş mezhepler" olarak zikreder. Ona göre sahabeden sonra tâbileri bulunan, taklit edilen ve tedvin edilmiş olan toplam on üç mezhep teşekkül etmiştir. Bu mezheplerin ilki Hasan-1 Basrî’nin (Ebû Saîd ö. 110/728) mezhebidir. ${ }^{36}$ Bundan sonra Ebû Hanîfe, Evzâî, Süfyân es-Sevrî, Leys

33 Zehebî, Siyeru 'Alâmi'n-Nübelâ, VIII, s. 91-92.

34 Ebu Hasan el-Kerecî, el-Fusûl fi'l-Usûl, s. 19. Buhârî’nin fikıhçılığı ve mezhep görüşleri hakkında bkz. Hamit Sevgili, İmam Buhârî, Ankara, Türkiye Diyanet Vakfı Yayınları, 2018.

35 Şarânî, Abdülvehhab b. Ahmed, el-Mîzânü'l-Kübra, Beyrut, Dâru'l-Kütübi'l-İlmiyye, 2018, s. 61.

36 Muhammed b. Hasan b. Arabi es-Sealibi Hacvi, el-Fikru's-Sâmî fì Târîhi Fıkhi'l-İslâmî, II, Rabat, Matbaatü İdâretü'l-Meârif, 1340, s. 118. 
b. Sa'd, Mâlik b. Enes, Süfyân b. Uyeyne, Muhammed b. İdris eş-Şâfiî, İshâk b. Râhûye, Ebû Sevr, Ahmed b. Hanbel, Dâvûd ez-Zâhirî, İbn Cerîr et-Taberî’nin müstakil mezhebi olmuştur. ${ }^{37}$ Benzer bir tasnifi Muhammed Sellâm Medkûr da yapmış fakat o, bunlara ilaveten Âmir eş-Şa'bî (ö. 104/722), Abdullah b. Şübrüme (ö. 144/761), İbn Ebî Leylâ, Şerîk b. Abdullah en-Nehâî’yi de (ö. 177/794) zikretmiştir. $^{38}$

Son asırda telif edilen hemen hemen bütün hukuk tarihi çalışmalarındaki mezhep tasnifleri bu isimler etrafinda şekillenmiştir. Bazı müellifler bu sayıyı, mezhep görüşlerinin daha belirgin olması ve kısmen de olsa günümüze kadar ulaşabilmesini esas alarak daha dar tutmuşlardır. Örneğin Abdülkerim Zeydan Evzâî, Süfyân es-Sevrî, Leys b. Sa ‘d, Davud ez-Zâhirî ve İbn Cerîr et-Taberî’yi zikretmekle iktifa etmiştir. ${ }^{39}$ Mustafa eş-Şelebî, ${ }^{40}$ Nâsır et-Tarîfîn ${ }^{41}$, Muhammed Hudarî Beg de ${ }^{42}$ müstakil mezhepleri dar çerçevede tutanlardandır.

Ömer Nasuhi Bilmen de müçtehit olup içtihat müessesesi devam etmeyen on yedi kişiyi sayar. Bunlar: İbrahim en-Nehâî, İbn Ebî Leylâ, İbni Şübrüme, Süfyân es-Sevrî, Zeydiliğin kollarından Sâlihiyye mezhebinin kurucusu Hasan b. Sâlih [b. Hay] (ö. 168/784-85), Evzâî, Amr b. Hâris (ö. 148/765), Leys b. Sa'd, Abdullah b. Ebî Cafer (ö. 132/ 749), İshâk b. Râhûye, Ebû Ubeyd Kâsım b. Sellâm (ö. 224/838), Ebû Sevr el-Bağdâdî, İbn Huzeyme, Muhammed b. Nasr el-Mervezî (ö. 294/906), Ebû Bekir b. Münzir en-Nisâbûrî (ö. 318/930 [?]), Dâvûd ez-Zâhirî ve İbn Cerîr et-Taberî'dir. ${ }^{43}$ Hayrettin Karaman'ın yaptığı tasnif ise birkaçı müstesna büyük oranda Fuat Sezgin'inkiyle örtüşmektedir.

Ahmed b. Hanbel'in mezhebi hakkında yapılan tartışmalar bir yana bırakacak olursak, bilinen ve günümüze ulaşan dört mezhebin dışındaki mezheplerin tasnifi hususunda, Hasan el-Basrî, Evzâî, Süfyân es-Sevrî, Leys b. Sa'd, Süfyân b. Uyeyne, İshâk b. Râhûye, Ebû Sevr, Dâvûd ez-Zâhirî, İbn Cerîr et-Taberî d1şındakilerde tam bir ittifak oluşmadığını söylemek mümkündür.

37 Hacevî, el-Fikru's-Sâmî, II, s. 118, III, s. 39.

38 Muhammed Sellâm Medkûr, el-Medhal li'l-Fıkhi'l-İslâmî, Kahire, Dâru'l-Kitâbu'l-Hadîs, 1996, s. 166.

39 Abdülkerim Zeydan, el-Medhal li Dirâsâti'ş-Şerîati'l-İslâmiyye, İskenderiye, Dâru Ömer b. Hattab, 2001, s. 178.

40 Muhammed Mustafa eş-Şelebî, el-Medhal fi'l-Fıkhı'l-İslâmî, Beyrut, Dâru'l-Câmiiyye, 1985, s. 205-206.

41 Nasr b. Akil b. Casir Tarîfî, Târîhu'l-Fıkhi'l-İslâmî, Riyad, Mektebetü't-Tevbe, 1997, ss. 110-115.

42 Muhammed Hudarî Beg, Târîhu't-Teşrîi'l-İslâmî, Beyrut, Dâru'l-Fikr, 1967, ss. 227-231.

43 Ömer Nasuhi Bilmen, Hukukı İslamiyye ve Istılahatı Fıkhiyye Kamusu, I, İstanbul, Bilmen Yayınevi, t.y., s. 313. 


\section{Fuat Sezgin'de Yaşamayan Sünnî Mezhepler}

Fuat Sezgin, fikıh mezheplerini dört gruba toplamıştır. 1. Dört mezhep, 2. Müstakil mezhepler, 3. Şia fikhı, 4. İbâdî fikhı.

Sezgin, yaşamayan sünnî mezhepleri "Müstakil Fıkıh Medreseleri” olarak adlandırır ve bunları bilinen dört mezhepten ayrı olarak inceler. Daha önce de ifade ettiğimiz üzere, zikredilen bu mezheplerin üzerinde tam anlamılla bir ittifak sağlanmış değildir. Sezgin de genellikle İslam hukuk tarihinde çok bilinenlere yer verirken az bilinen birkaçının da mezhep sahibi olduğunu ifade etmiştir. Ancak, onun da açıklamalarından anlaşılacağı üzere, bu tasnif altında incelediği bazıları için, "F1kıhta medrese-ekol sahibi" terimini kullanırken kimileri için de kullanmaz. Onun tasnifinde de görüleceği üzere bazı fakihler bir mezhebin içinde mütalaa edilirken müstakil müçtehit olarak da addedilmiştir. Bunu şöyle açıklayabiliriz:

Mezheplerin teşekkülünün hicri III. asrın ortalarında tamamlandığı hatta Hanbelî mezhebinin tam anlamıla teşekkülünün talebeleri vasıtasıyla daha geç bir tarihe tekabül ettiği düşünülmektedir. Hatta George Makdisî’nin öğrencilerinden Christopher Melchert'e göre, günümüzde aşina olduğumuz anlamıyla mezhepler hicri V. yüzyıldan sonra görülmeye başlanmıştır. ${ }^{44}$ Mezheplerin bir imam etrafında ortaya çıkışı ve bundan sonraki süreçte tedvin, tedris ve belli coğrafyalarda yayılıp büyük kitleler tarafından benimsenmesi; dolayısıyla kurumsallaşması için ön görülen bu süre, makul bir süredir. Bu dönem ayrıca mezhebe ait muhtasar metinlerin yazıldığı ve mezhebin öncü imamlarının (reîsü'l-mezheb) ortaya çıktığı dönem olarak kabul edilir. Bunun örneği Hanefîlerde Kerhî (ö. 340/952), Şâfîlerde ise İbn Süreyc (ö. 306/918), Hanbelîlerde Ebûbekir el-Hallâl'dır (ö. 311/923). Bu fakihler mezheplerini sistematik hale getiren kişiler olarak da bilinir. Mezheplerin kurucu imam ve talebelerinden sonra yaklaş1k bir asır sonrasına tekabül eden bu dönem içinde bazı fakihlerin, mezhep fikhına dair usul kaidelerini tertip ederek, hadisleri ve füru meseleleri toplayarak tedvin etme çabaları göze çarpmaktadır. Fıkhî çalışmalarıyla öne çıkan bu fakihlerden bazıları mezhebin kurucu imamından ya da talebelerinden üstün tutulmuştur. Örneğin Endülüs'te Mâlik' in bazı talebeleri, özellikle de İbnü'l-Kâsım (ö. 196/806) III. yüzyılın sonlarına kadar Mâlik' in kendisinden bile üstün bir otorite olarak görülmüştür. ${ }^{45}$ Irak’ta Şâfiîler'in üstadı olan İbn Süreyc, Şâfî̀ mezhebini en iyi bilen âlim olarak gösterilmiş ve Müzenî dâhil İmam Şâfî̀’nin bütün öğrencile-

44 Christopher Melchert, “Sünnî F1kıh Mezheplerinin Teşekkülü”, M.Ü. İlahiyat Fakültesi Dergisi, çev. Nail Okuyucu, 41 2011/2, 221-236.

45 Christopher Melchert, "Sünnî Fıkıh Mezheplerinin Teşekkülü”, s. 223. 
ri ve müntesibi âlimlerden üstün tutulmuştur. ${ }^{46}$ Fuat Sezgin'in bazı kişileri, bir mezhebe bağlı olmasına rağmen müstakil müçtehid olarak görmesinin sebebi, bu fakihlerin zamanlarında mezhebin tam anlamıyla teşekkül etmemesi ve onların müstakil müçtehit kadar itibar görmesidir.

Sezgin eserinde yaptığ tasnifte, müstakil mezhep kurucusu olduğu ittifakla kabul edilen İbn Cerîr et-Taberî’ye (ö. 310/923) müstakil bir başlık altında yer vermezken ondan sonra mezhebi geliştiren, mezhebin eserlerini telif eden Muâfâ b. Zekeriyya'ya (ö. 390/1000) yer vermiştir. Bunu da yukarıda zikrettiğimiz gerekçeye bağlamak mümkündür. Her ne kadar o bu bölümde Taberî’ye özel bir başlık açmamış olsa da eserenin ilerleyen bölümlerinde onun müstakil müçtehit olduğundan söz etmiştir. ${ }^{47}$ Yine Sezgin, İshâk b. Râhûye (ö. 238/853), Süfyân b. 'Uyeyne (ö. 198/814) ve Ebû Sevr (ö. 240/854) gibi İslam hukuk tarihi eserlerinde müstakil mezhep sahibi oldukları bildirilen kişilere de yer vermemiştir. Sezgin'in yaşamayan mezhepler için yaptığı bu tasnif kısmen veya tamamen sonraki yazarlar tarafından da kullanılmıştır. ${ }^{48}$

Bu kısımda yaşamayan mezhepleri sadece Sezgin'in zikrettiği kadarıyla ele alacağız. Bu mezheplerin bir kısmının usul ve görüşleri hakkında kısmi bilgiler günümüze kadar ulaşabildiği için usul ve metodolojileri hakkında müstakil çalışmalar yapılabilmiştir. Örneğin Evzâî, İbn Ebî Leylâ Süfyân es-Sevrî, İbn Cerîr et-Taberî, Davud ez-Zâhirî hakkında çalışma yapılanlardandır. Fakat İbn Eyyüb el-Abbâdânî, Yunus el-Eylî, İbn Yesâr, Yahyâ b. Âdem ve Muâfâ b. Zekeriyya gibi fahik ve muhaddislerin, bazı rivayetleri dışında günümüze ulaşan mezhep usul ve görüssleri bulunmamaktadır. Bunlar hakkındaki malumatlar, zamanında tâbilerinin bulunduğu yönündedir.

\subsection{Evzâî (ö. 157/774) Mezhebi}

Tam adı Ebû Amr Abdurrahmân b. Amr b. Yuhmid el-Evzâî'dir. (88/707) tarihinde doğmuş, Şam ve Beyrut'ta yaşamıştır. Katâde b. Diâme, Atâ b. Ebî Rebâh ve Zührî gibi hocalardan ders okumuş, hadis dinlemiştir. İlimdeki mertebesi, mükemmel ahlâk1, zühdü, fikıh bilgisindeki enginliği gibi hususlarda temayüz etmiştir. Âlimlerden bazıları onu Süfyan-1 Sevrî’den üstün görmüştür. (ö. 157/774) ${ }^{49}$

46 Şükrü Özen, “İbn Süreyc”, TDV İslam Ansiklopedisi, XX, İstanbul, 1999, s. 363-366.

47 Sezgin, a.g.e., II, s. 642-643.

48 Bkz. Hayrettin Karaman, İslam Hukuk Tarihi, İstanbul, İz Yayınc1lık, 2011, s. 211-221; Abdülkerim Ünalan, "İslam Hukuku ve Ana Özellikleri”, Dicle Üniversitesi İlahiyat Fakültesi Dergisi, c. 1, Diyarbakır, 1999, s. 93. (79-118); Abdülkadir Şener, "İslâmda Mezhepler ve Hukuk Ekolleri”, Ankara Üniversitesi Illahiyat Fakültesi Dergisi, cilt XXVI, 1983, ss. 371-406.

49 Fuat Sezgin, a.g.e., Arapçaya çeviren Mahmud Fehmî Hicâzî, I, Riyad, Câmiatü el-İmam Muhammed b. Suud el-İslamiyye, 1991, s. 243. 
Sezgin'e göre Evzaî müstakil medrese (ekol) ve mezhep sahiplerinden biridir. Bu mezhep Şam'da doğmuş ve geniş bir yayılma alanı bulmuştur. Hicri II. ve III. asırda Mağrib ve Endülüs'te kendisine büyük taraftar kitlesi bulan Evzaî mezhebi, bundan sonraki zaman diliminde Malikî ve Şafîi mezheplerinin bölgede hâkimiyeti güçlendirmesiyle birlikte hızla kaybolmaya başlamıştır. ${ }^{50}$

Evzâî'nin eserlerinden günümüze ulaşan yalnızca Kitâbü Siyeri'l-Evzâî' dir ve Şâfiî’nin el-Ümm adlı eseri içinde bir bölüm olarak yer almıştır. Ebû Hanîfe'nin öğrencisi Ebû Yusuf buna er-Red alâ Siyeri 'l-Evzâi isimli bir reddiye yazmıştır.

Sezgin'in araştırmalarına göre onun, Kitâbü's-Sünen fi'l-fikh ve Kitâbü'lMesâ'il fi'l-fikh adlı iki eseri daha bulunmaktadır. Bu eserler günümüze ulaşmamakla birlikte bu iki kitabın muhteviyatına dair bilgiler ve bazı alıntılar sonraki dönem kaynaklarda bulunmaktadır. ${ }^{51}$ Kaynaklarda bunlardan başka Evzâi'ye nispet edilen başka bir eser bilinmemektedir. Ancak Sezgin'e göre Evzâ̂'’nin bunlardan başka eserleri de bulunmaktadır. İbn Ebî Hâtim'in el-Cerh ve Ta 'dîl adlı eserinde bu kitapların varlığına işaret edildiğini söyleyen Sezgin'e göre bu eserlerde Evzâî'nin fikıh anlayışına dair bazı ipuçları bulunmaktadır. ${ }^{52} \mathrm{Bu}$ eserler ve muhtevaları hakkında İbn Ebî Hâtim'in ilgili eserine bakılabilir. Sezgin'in bahsettiği bu eserlerin bir kısmı gayet kısa olup kitap veya risaleden ziyade mektup tarzındadır. ${ }^{53}$

\section{2. İbn Eyyüb el-Abbâdânî (ö. 347/958) Mezhebi}

Sezgin'in müstakil mezhep imamları arasında zikrettiklerinin ikincisi, İbn Eyyüb el-Abbâdânî ismiyle meşhur Ahmed b. Süleyman'dır. 243/862 yılında Şam'da doğmuştur. İlim tahsilinin ardından burada kadılık yapmış, sonraları Bağdat ve Sâmerrâ'ya gelmiş, çeşitli muhaddislerden hadis dinlemiş, ${ }^{54}$ ardından tekrar Şam'a dönmüş ve burada vefat etmiştir (347/958). Suriye'de Evzâî'nin mezhebini okutanların sonuncusudur. ${ }^{55}$

Bizim görebildiğimiz kadarıyla İslam hukuk tarihi araştırmacıları eserlerinde İbn Eyyüb el-Abbâdânî’yi müstakil mezhep kurucusu olarak zikretmemiştir.

50 Sezgin, a.g.e., I, s. 243. Evzâ̂’’nin teracimi için bkz. İbn Sad, Muhammed, et-Tabakatü 'l-Kübrâ, VII, Beyrut, Daru's-Sader, t.y., s. 488; Muhammed Abdullah b. Müslim b. Kuteybe Dîneverî, el-Maarif, thk. Servet Ukkâşe, I, Kahire, Heyetü'l-Amme Misriyye, 1992, s. 496; Taberî, Muhammed b. Cerîr, Târîhu 't-Taberî, Beyrut, Dâru’t-Türâs, 1387, s. 11, 656.

51 Sezgin, a.g.e., I, s. 244.

52 Sezgin, a.g.e., I, s. 244.

53 Bkz.: İbn Ebî Hâtim, Ebu Muhammed Abdurrahman, el-Cerh ve't-Ta 'dîl, I, Beyrut, Dâru İhyâi't-Türâsi'l-Arabî, 1952, s. 186-187; Sezgin, a.g.e., I, s. 245.

54 Zehebî, Siyeru Alâmi'n-Nübelâ, XV, s. 479.

55 Sezgin, a.g.e., I, s. 245-246. 
Hayrettin Karaman da el-Abbâdânî'nin bu yönünü Fuat Sezgin'in eserine atfen zikreder. Tarih ve teracim eserleri sadece, el-Abbâdânî'nin hadis hıfzı ve nakli konusunda güvenilir oluşu, ${ }^{56}$ kendisinden pek çok âlimin hadis dersi aldığı hakkında bilgi vermektedir. ${ }^{57}$

\section{3. İbn Ebî-Leylâ (ö. 148/765) Mezhebi}

Sezgin'in müstakil mezhep imamları kategorisinde zikrettiği bir başka kişi de Muhammed b. Abdurrahmân İbn Ebî-Leylâ'dır. 74/693 yılında doğmuştur. Kûfelidir. Müstakil müçtehit fakihlerdendir. Emevî ve Abbâsî dönemlerinde otuz üç yıl Kûfe kadılığg yapmıştır. Fıkıh ilminde mâhirdir. Ebû Hanife'den önce içtihatlarında rey metodunu benimsemiştir ${ }^{58}$ ve rey metodunun gelişmesinde önemli bir yere sahiptir. Mezhebi çok uzun yaşamamış ve kendisinden sonraki nesiller tarafından takip edilmediğinden unutulmuştur. Sezgin'e göre İbn Ebî Leylâ'nın bilinen tek eseri, Kitâbu'l-Ferâiz' dir $^{59}$ ancak günümüze ulaşmamıştır. Görüşleri, Ebû Yusuf tarafindan, İhtilâfü Ebî Hanîfe ve İbn Ebî Leylâ adlı eser içerisinde derlenmiştir (nşr. Ebü'l-Vefâ el-Efgānî, Kahire 1357). ${ }^{60}$

\subsection{Süfyân es-Sevrî (ö. 161/778) Mezhebi}

Tam adı Ebû Abdullâh Süfyân b. Saîd b. Mesrûk es-Sevrî el-Kûfî’dir. 97/715 yılında dünyaya gelmiştir. Muhaddis, kelamcı ve zühd ehli biridir. Küçük yaşta asrının önemli âlimlerinden biri olan babasının yanında hadis ve diğer ilimleri öğrenmiş ve genç yaşta hadis rivayet etmeye başlamıştır. İlerleyen zamanlarda Abbâsî Halifesi Mansûr tarafından kendisine kadılık teklifi yapıldıysa da bunu kabul etmemiştir. Halife'nin teklifini kabul etmemesinden ve bazı eleştirilere maruz kalmasından ötürü ömrünün geri kalanını gizli yaşamak zorunda kalmıştır. Süfyân es-Sevrî hadisleri fikıh baplarına göre tasnif eden ilk muhaddislerden sayılır. O, Küfe'de müstakil bir mezhep inşa etmiştir. Ehli hadis taraftarlarındandır. ${ }^{61}$ Süfyân es-Sevrî’nin mezhebi de uzun süre devam etmemiştir. ${ }^{62}$

56 Haldun el-Ahdab, Zevâidu Târîhu Bă̆dat, III, Dımaşk, Dâru'l-Kalem, t.y., s. 503.

57 Bkz. Hatib el-Bağdadî, Ahmed b. Ali, Târîhu Bă̆dat, IV, Beyrut, Dâru'l-Kütübi'l-İlmiyye, t.y., s. 178; Cezerî, Ebu'l-Hasan Ali. el-Lübâb fî Tehzîbi'l-Ensâb, II, Beyrut, Dâru's-Sader, 1980, s. 309.

58 İbn Nedîm, Ebu'l-Ferec Muhammed, el-Fihrist, thk. İbrahim Ramazan, I, Beyrut, Dâru'l-Marife, 1997, s. 252.

59 İbn Nedîm, el-Fihrist, I, s. 252.

60 Sezgin, a.g.e., I, s. 246-247.

61 Süfyan es-Sevrî ve fikıh ilmindeki yeri hakkında daha fazla bilgi için bkz. Abdülkadir Tekin, "Süfyan es-Sevrî’nin F1kıhçılığı”, Amasya İlahiyat Dergisi, say1 5, 2015, s. 115-143; Ömer Faruk Akp1nar, "Süfyân es-Sevrî’nin Hayatı ve Eserleri”, Usûl: İslam Araştırmaları, sayı 22, 2014, s. 115-167.

62 Sezgin, a.g.e., I, s. 247-248. Süfyân es-Sevrî’nin daha geniş biyografísi için bkz. Muhammed Abdullah b. Müslim b. Kuteybe Dîneverî, el-Maarif, I, s. 497; İbn Sad, et-Tabakatü 'l-Kübrâ, 
Eserleri:

Kaynaklarda Sevrî'ye ait farklı eserler zikredilmektedir. ${ }^{63}$ Sezgin'in ona ait olduğunu tespit ettiği eserler şunlardır:

1. et-Tefsîr. Hicri II. yüzyıla ait ilk sistemli rivayet tefsiri çalışmalarından biridir. Basılmıştır (Râmpûr 1965).

2. el-Ferâ'iz. Bu konuda yazılmış ilk eserlerdendir. Zâhiriyye Kütüphanesi'nde bir nüshası bulunmaktadır (Mecmua, nr. 38, vr. 27b-37b). Eser, Abdülazîz b. Abdullah el-Helîl tarafindan el-Ferâ 'iz adıyla yayımlanmıştır (Riyad 1410).

3. el-İtikâd: Takıyyüddin İbn Teymiyye tarafindan gözden geçirilerek oluşturulan bir tenkih nüshası, Şam Zâhiriyye Kütüphanesi'nde bulunmaktadır (Mecmua, nr. 139/14, vr. 191a-192a). ${ }^{64}$

4. Mimmâ Esnede Süfyân es-Sevrî: Hicri III. Asrın sonlarında vefat eden Abdullah b. Muhammed b. Saîd b. Ebû Meryem'in gözden geçirerek istinsah ettiği bir nüshadır. Eser Şam Zâhiriyye Kütüphenesi’nde (Mecmua, nr. 90, vr. 39a-47a) bulunmaktadır.

5. Risâla fi'z-Zühd ilâ Abbâd b. Abbâd b. Habîb el-Ateki ${ }^{65}$ : Süfyân esSevrî'nin zühd ve takva konularında öğrencilerine ve dostlarına yazdığı risale tarzı mektuplardan biridir. ${ }^{66}$

6. Vasiyyet: Ali b. Hasan es-Sülemî’ye gönderilmiş hikmet ve bazı tavsiyeleri içeren bir mektuptur. ${ }^{67}$ Sezgin, Süfyân-1 Sevrî’nin Ali b. el-Hasan es-Sülemi'ye gönderdiği vaaz ve nasihat içerikli mektuplarının diğer tabakat kitaplarında da geçtiğinden söz eder.

7. el-Câmi : Daha ziyade sahâbe, tâbiîn ve tebeu't-tâbiîn fakihlerine ait fikhî görüşleri derlediğii kendi ictihadi görüş ve tercihlerini de içeren bir eserdir. ${ }^{68}$

VI, s. 371; İbn Nedîm, el-Fihrist, I, s. 314. Zehebî, Ebû Abdullah, Tezkiretü'l-Huffâz, I, Beyrut, Dâru’t-Turâsi'l-‘Arabî, 1374, s. 206; Hatib el-Bağdâdî, Târihu Bă̆dâd, IX, s. 172.

63 Bkz. Recep Özdirek - Ali Hakan Çavuşoğlu, "Süfyan es-Sevri”, TDV İslâm Ansiklopedisi, XXXVIII, İstanbul, 2010, s. 23-28.

64 Ayrıca bkz. Zehebî, Tezkiretü'l-Huffâz, I, s. 206-207.

65 Dia maddesinde bu eserin yazıldığı kişi için "Risâle ilâ 'Abbâd b. 'Abbâd el-Ersûfì" şeklinde zikredilmiştir. Bkz. Recep Özdirek - Ali Hakan Çavuşoğlu, "Süfyân es-Sevrî", Türkiye Diyanet Vakfi Íslâm Ansiklopedisi, XXXVIII, İstanbul, 2010, s. 23-28.

66 İbn Ebî Hâtim, el-Cerh ve 't-Tadîl, I, s. 18; İbn Hacer el-Askalânî, Tehzîbu't-Tehzîb, V, Hindistan, Dâru Matbaati'l-Mearif, 1326, s. 97.

67 Ebu Nuaym, Hilyetü'l-Evliyâ, VII, s. 82-85.

68 Bkz. Recep Özdirek - Ali Hakan Çavuşoğlu, "Süfyân es-Sevrî", Türkiye Diyanet Vakfi İslâm Ansiklopedisi, XXXVIII, İstanbul, 2010, s. 2328-. 
Sezgin, Sevrî’nin eserleri hakkında son bir mülahazada bulunur. Bulduğu bir kütüphane fişine göre, Halife Harun er-Reşid'in Süfyân-1 Sevrî’ye olan bir sorusunu ve Sevrî'nin de ona cevabını konu alan bir risale daha bulunmaktadır (Dâru'l-Kütüb, Kahire, Mecmua, nr. 155). Fakat Sezgin'in kanaatine göre eğer böyle bir eser mevcut ise halifenin Mehdibillah olması gerekmektedir. ${ }^{69}$

\subsection{Yunus el-Eylî (ö. 159/775) Mezhebi}

Müstakil bir mezhebi olduğu hakkında kesin bir malumat bulunmayan ancak Sezgin'in mezhep sahipleri kategorisinde zikrettiği fakihlerden biri de Yunus el-Eylî’ dir. Tam adı Ebû Yezîd Yunus b. Yezîd b. Ebi'n-Necâd'dır. İbn Şihâb ez-Zührî’nin (ö. 124/742) talebesi ve râvîsi olmuştur. Kendisinden el-Leys b. Sa'd (ö. 175/791), Evzâî (157/774), Abdullah b. Mübârek (ö. 181/797), Abdullah b. Vehb (ö. 197/813) gibi muhaddisler hadis almışlardır. Yunus el-Eylî fikıhtan ziyade hadis sahasında tanınmıştır. Muhtemelen Yukarı Mısır'da vefat etmiştir. ${ }^{70}$

Sezgin'in tespitlerine göre Müdevvene yazarı (Sahnûn), Yunus el-Eylî’nin ufak hacimli bir fikıh risalesinin olduğunu belirtmiştir. ${ }^{71}$

\section{6. İbn Yesâr (v. 170/786) Mezhebi}

Tam adı Muâviye b. Ubeydillah b. Yesâr el-Eşarî’dir. Soyu Taberiyye (Filistin-Ürdün $)^{72}$ civarındandır. (100/718) yılında doğmuştur. Özellikle hadis ve edebiyat alanında söz sahibi olmuştur. Bir müddet halife Mehdî’nin kâtipliğini yaptıktan sonra vezirlik makamına yükselmiştir. Kitâbu'l-Harâc isimli bir eseri vardır. (170/786) yılında Bağdat’ta vefat etmiştir. ${ }^{73}$ Sezgin'e göre müstakil mezhep sahiplerindendir.

69 Sezgin, a.g.e., I, s. 248.

70 Sezgin, a.g.e., I, s. 249. Ayrıca bkz. İbn Sad, Ebu Abdullah Muhammed, et-Tabakâtü'l-Kübrâ, thk. Abdulkadir Atâ, VII, Beyrut, Dâru'l-Kütübi'l-İlmiyye, 1990, s. 360; Buhârî, Muhammed b. İsmail, et-Târîhu'l-Kebîr, VIII, Haydarabad, Dâiretü'l-Meârifi'l-Osmaniyye, t.y., s.406.

71 Sezgin, a.g.e., I, s. 249.

72 Bazı çalışmalarda Taberiyye nisbesi Taberistan. Hâlbuki Taberistan İran'ın kuzeyinde günümüzde Mâzenderan adını taşıyan eyalet iken Taberiyye bugünkü Ürdün, Filistin ve Suriye üçgenindeki Cûlan (Golan) tepelerinin güneyinde bulunan bir köydür. Köyün yanında suyu tatlı olan bir göl bulunmaktadır. İbn Asâkir'in onun Dımaşk asıllı olduğuna dair farklı bir aktarımı da bu düşüncemizi desteklemektedir. Bkz. İbn Asâkir, Ebu'l-Kâsım Ali, Târîhu Medîneti Dımaşk, thk. Amr b. Garâme, LIX, Beyrut, Dâru'l-Fikr, 1995, s. 249.

73 Sezgin, a.g.e., 1, 249. İbn Yesâr hakkında daha geniş malumat için bkz.: İbn Asâkir, Târîhu Medîneti Dımaşk, 38, 149, LIX, s. 249; Zehebî, Şemseddin, Siyeru 'Alâmi'n-Nübelâ, Beyrut, Müessesetü'r-Risâle, 1985, 7, 398; Ziriklî, Hayreddin, el- 'Alâm, VII, Beyrut, Dâru'l-İlim li'lMelâyîn, 2002, s. 262. 


\subsection{Leys b. Sa'd (175/701-788) Mezhebi}

Hakkında mezhep imamı olduğu ittifak edilenlerdendir. Tam adı Ebü'l-Hâris elLeys b. Sa‘d b. Abdirrahmân el-Fehmî’dir (ö. 175/791). (94/714) yılında Aşağı M1sır' da Kahire yakınlarındaki Karkaşende (Kalkaşende) köyünde dünyaya gelmiştir. Fakih ve muhaddistir. Şâfî̀’nin mezhebinden sonra Enes b. Mâlik'in mezhebinden daha meşhur olmuştur. Fakat kendisinden sonra ekolünün temsilcileri ve tâbileri, mezhebin ayakta durabilmesi için gerekli ihtimamı göstermemişlerdir. ${ }^{74}$

\section{Eserleri:}

1. Hadîs: Bir hadis cüzü mahiyetinde olan bir eser mecmualar içinde bulunmaktadır. Bkz.: Köprülü 3/372 (136-154 vr.), Şam Zâhiriyye Kütüphanesi (Mecmua nr. 19, 1-18 vr.).

2. Meclisun min Fevâidi'l-Leys ve'r-Ruhsatü fî Takbîli'l-Yed ${ }^{75}$ : Şam Zâhiriyye Kütüphanesi (Mecmua nr. 10/115).

3. Risâletün ilâ Enes b. Mâlik: F1kıh konularını muhtevi bir mektuptur (risale). İbn Kayyim el-Cevziyye I' 'lâmu'l-Muvakkı 'în'de bu eserden söz etmiştir. ${ }^{76}$

\subsection{Yahyâ b. Âdem (ö. 202/818) Mezhebi}

Fuat Sezgin'in müstakil mezhep sahibi olarak nitelediği fakihlerdendir. Tam adı Ebû Zekeriyyâ Yahyâ b. Âdem b. Süleymân el-Kureşî el-Ümevî el-Kûfî’ dir. Şaşılığından dolayı “el-Ahvel” lakabıyla da anılmıştır. Kufe' de yaşamıştır. Şerîk b. Abdillâh b. Hâris en-Nehaî (ö. 177/794) ve Süfyân es-Sevri’ den (ö. 161/778) dersler almıştır. F1kıh, hadis ve kıraat ilimlerinde âlimdir. Ahmed b. Hanbel ve Yahya b. Maîn (ö. 233/848) gibileri ondan dersler almıştır. Yahyâ b. Âdem ilimde otorite sahibidir. Diğer imamlara tâbi olmayıp kendi müstakil görüşlerini oluşturmuştur. Sezgin bunların dışında onun hakkında çok fazla bilginin bulunmadığını söyler. ${ }^{77}$

74 Sezgin, a.g.e., I, s. 250. Leys b. Sa 'd hakkında daha geniş bilgi için bkz. İbn Asâkir, Târîhu Medineti Dımaşk, L, s. 341; İbn Hallikan, Ebu'l-Abbas Şemseddin, Vefâyâtü'l- 'Ayân ve Enbâu Ebnâi'z-Zamân, thk. İhsan Abbas, IV, Beyrut, Dâru Sader, 1994, s. 127; Zehebî, Siyerü 'Alâmi'n-Nübelâ, VIII, s. 136; İbn Hacer el-Askalânî, Lisânü'l-Mîzân, Beyrut, Müessesetü'l-Alemi, VII, 1971, s. 347; İbn Ebî Hâtim, el-Cerh ve't-Tadîl, V, s. 229; Ziriklî, el- 'Alâm, V, s. 248.

75 Eserin "Meclisun min Fevâidi'l-Leys" kısmı, Dia Maddesinde bir hadis cüzü olarak zikredilmiştir. Bkz. Şükrü Özen, "Leys b. Sa'd”, TDV İslâm Ansiklopedisi, XXVII, İstanbul, 2003, s. 164-168.

76 Bkz.: İbn Kayyim el-Cevziyye, Ebu Abdullah Muhammed, I'lâmu'l-Muvakkı 'în an Rabbi'lÂlemîn, I, Suudi Arabistan, Dâru İbnü'l-Cevzî, 1423, s. 53.

77 Sezgin, a.g.e., I, s. 251. Yahyâ b. Âdem hakkında daha geniş bilgi için bkz. Zehebî, Siyerü 'Alâmi'n-Nübelâ, II, s. 631; Mizzî, Yusuf b. Abdurrahman, Tehzîbu'l-Kemâl fî Esmâi'r-Ricâl, thk. Beşşar Avvad, XXXI, Beyrut, Müessesetü'r-Risâle, 1980, s. 188; Ebu'l-Fidâ İsmail ibn Kesir, et-Tekmîl fi'l-Cerhi ve 't-Tadîl, thk. Şadi b. Muhammed, II, Yemen, Merkezü'n-Numan, 2011, s. 154; İbn Hacer el-Askalânî, Tehzîbu't-Tehzîb, XI, 154. 


\section{Eserleri:}

1. el-Harâc: İslam maliye hukukuna dairdir. On iki varaktan oluşan bir nüshas1 Paris Kütüphanesi'nde 6030 numarada mevcuttur. Ahmed Şakir bu eseri tahkik ederek h. 1347 yılında Kahire'de neşretmiş ardından İngilizceye çevirmiştir. ${ }^{78}$

\section{9. Şüreyh b. Yûnus (ö. 235/849) Mezhebi}

Zaman zaman Hz. Ömer'in Küfe kadısı olarak tayin ettiği Kadî Şüreyh b. el-Hâris el-Kûfî (ö. 80/699 [?]) ile karıştırılır. Şüreyh b. Yûnus, Fuat Sezgin tarafindan müstakil mezhebi olduğu bildirilen şahıslardan biridir. Tam adı Ebû'l-Hâris Şüreyh b. Yûnus el-Mervezî'dir. Bazı kaynaklarda ismi Süreyc olarak geçmektedir. ${ }^{79}$ Fakih, müfessir ve muhaddistir. Bağdat'ta yaşamıştır. Müslim, Ebû-Hâtim er-Râzî ve daha pek çokları kendisinden ders almıştır. ${ }^{80}$

Eserleri:

Şureyh b. Yunus'un Kitâbu'l-Kadâ isimli bir eseri bulunmaktadır. Eser, Şam Zâhiriyye Kütüphanesi'nde (Mecmua nr. 229, 113-125 vr.) ve Feyzullah Efendi Kütüphanesi ikinci kısımda (Mecmua nr. 506, 51-62 vr.) bulunmaktadır. ${ }^{81}$

\subsection{Davud ez-Zâhirî (ö. 270/884) Mezhebi}

Sezgin'e göre sünnî mezhepler arasında sadece Kur'an ve sünnetin zahirine dayanan bir ekolün sahibidir, mezhebin tüm görüşleri bu yolla elde edilmiştir. Bu sebeple onun mezhebine "Zâhiriyye" denilmiştir. (200/815) yılında Kûfe'de doğan Ebû Süleymân Dâvûd b. Alî b. Halef el-İsfahânî, bu mezhebin kurucusudur. Basra, Bağdat ve Nîşâbur'da eğitim görmüş, sonra Bağdat'a yerleşmiştir. Babası Hanefî mezhebine mensup olmasına rağmen o, hocası Ebû Sevr el-Kelbî'nin de tesiriyle Şâfiî mezhebini tercih etmiştir. Daha sonra Şâfîi mezhebinden de ayrılmış herhangi bir imama tâbi olmamıştır. Kendi mezhebinin sistematiğini kuran Davud ez-Zâhirî kıyası terk etmiştir. (270/884) yılında Bağdat’ta vefat etmiştir. Hicri IV. yüzyıla gelindiğinde mezhebi Irak, Fars, Horasan ve Umman bölgelerine yayılmış ve pek çok tâbisi olmuştur. Zâhirî mezhebi, Muvahhidler Hanedanı'nın Yakub b. Mansur zamanında (570/1184-595/1199) devletin resmi mezhebi kabul edilmiştir. ${ }^{82}$

78 Sezgin, a.g.e., I, s. 251.

79 İbn Nedîm, el-Fihrist, I, s. 282.

80 Sezgin, a.g.e., 252. Şüreyh b. Yunus hakkında daha geniş malumat için bkz. İbn Hallikan, Vefeyâtü'l- 'Ayân, I, s. 67; İbnü'l-Müstevfi, el-Mübârek b. Ahmed, Târîhu Erbil, thk. Sami b. Seyyid Hammas, II, Irak, Dâru'r-Reşîd, 1980, s. 322; İbn Sa'd, et-Tabakâtü'l-Kübrâ, VII, s. 255.

81 Sezgin, a.g.e., I, s. 252.

82 Sezgin, a.g.e., I, s. 252-253. Davud ez-Zâhirî hakkında daha geniş bilgi için bkz. İbn Nedîm, el-Fihrist, I, s. 267; İbnü'l-İmâd, Ebü'l-Felâh Abdülhay b. Ahmed b. Muhammed es-Sâlihî 
Eserleri:

Fuat Sezgin'in ifadelerine göre İbn Nedîm onun eserlerinin 157 kadarının ismini zikretmiştir. Fakat günümüze hiçbir eseri ulaşmamıştır. F1khî görüşleri öğrencileri tarafından sonraki nesillere intikal ettirilmiş, Muhammed b. Hasan eşŞattî (ö. 1307/1890) talebelerinin rivayetlerinden hareketle Dâvûd'un görüşlerini bir araya getirmiş ve bunu Risâle fì mesâ'ili'l-İmâm Dâvûd ez-Zâhirî, (Şam 1330/1912) isimli eseriyle neşretmiştir. ${ }^{83}$

\subsection{Ebû Bekir Muhammed ez-Zâhirî (297-910) Mezhebi}

Davud ez-Zâhirî’nin oğludur. Babasının mezhep görüşlerini devam ettiren biri olarak bilinmesine rağmen Sezgin, onu müstakil mezhep sahipleri kategorisinde zikretmiştir. Onun ifadeleriyle Muhammed ez-Zâhirî babasının vefatından sonra mezhebin başına geçmiştir. Bu sıralarda on altı yaşlarındadır. Kaynaklar babasının oğlundan hadis dinlediğini bildirir. Sezgin, oğlunun babasından daha fakih olduğunu kaydeder. Bu sebeple olsa ki onu müstakil müçtehitler listesine dâhil etmiştir. ${ }^{84}$

Eserleri:

Sezgin Muhammed ez-Zâhirî'ye dair daha geniş malumatı eserinin ilerleyen bölümlerinde yer vereceğini söylemekteyse de araştırmalarımız neticesinde rastlayamadık. Tespit edebildiğimiz kadarıyla Muhammed ez-Zâhirî’nin bazı eserleri şöyledir:

Kitâbü'z-Zehre: Günümüze ulaşan tek eseridir. Onun bu eserini bir aşk sebebiyle kaleme aldığı rivayet edilir. ${ }^{85}$ Muhammed b. Davud'un kaynaklarda zikredilen diğer eserleri şunlardır: Kitâbü'l-İnzâr, Kitâbü'l-İ zâr, Muhtârü'leş'âr, el-Îcâz fi'l-fikh, el-Berâ'e, et-Tekassî fi'l-fikh, el-Vusûl ilâ ma'rifeti'l-

el-Hanbelî, Şezerâtü'z-Zeheb fi Ahbâri men Zeheb, thk. Mahmud Arnavut, III, Beyrut, Dâru İbn Kesîr, 1986, s. 298; Şîrâzî, Ebu İshak, Tabakâtü'l-Fukahâ, thk. İhsan Abbas, I, Beyrut, Dâru'r-Râid el-Arabî, 1970, s. 92; Zehebî, Siyeru 'Alâmi'n-Nübelâ, XIII, s. 102; Sıbt İbnü'l_ Cevzî, Şemseddin Ebu'l-Muzaffer, Mir'âtü'z-Zamân fî̀ Tevârîhi’l- 'Ayân, XVI, Dımaşk, Dâru'r-Risâle el-Alemiyye, 2013, s. 87; İbn Hallikân, Vefeyâtü'l- 'Ayân, IV, s. 259.

83 Sezgin, a.g.e., I, s. 253.

84 Sezgin, a.g.e., I, s. 253-254. Muhammed ez-Zâhirî hakkında daha geniş bilgi için bkz. İbn Hallikân, Vefeyâtü'l- 'Ayân, IV, s. 259; Zehebî, Siyeru 'Alâmi'n-Nübelâ, XIII, s. 109; Kehhâle, Ömer Rizâ, Mu 'cemü'l-Müellifîn, IX, Beyrut, Mektebetü'l-Müsennâ, t.y., s. 296; Ziriklî, el'Alâm, VI, s. 120; Saffet Köse, "İbn Dâvûd ez-Zâhirî”, TDV İslâm Ansiklopedisi, XIX, İstanbul, 1999, s. 410411-.

Ayrıca bkz. Zehebî, Tezkiretü'l-Huffâz, I, s. 206-207.

Hatîb el-Bağdâdî, Târîhu Bağdat, II, s. 324. 
usûl, İhtilâfü mesâ'ili s-șahâbe, el-Ferâ 'iż, el-Menâsik ve Muhammed b. Cerîr et-Taberî, Abdullah b. Şerşîr ile İbrâhim ed-Darîr'e reddiye olarak yazdığ 1 Kitâbü'l-Intisâr ${ }^{86}$

\subsection{Nebîl (v. 287/900) Mezhebi (İbn Ebî Âsım)}

Tam künyesi, Ebû Bekir Ahmed b. Amr b. Ebî Âsım ed-Dahhâk eş-Şeybânî en-Nebîl ez-Zâhirî' dir. (206/882) yılında doğmuştur. İlim tahsili için uzun seyahatlerde bulunmuş, daha sonra ilk olarak Basra'ya yerleşmiş ve nihayet İsfehan'a giderek orada ikamet etmiştir. Hicri 269-282 yılları arasında kadılık görevinde bulunmuştur. Nebîl, fikıh ve hadîs ilimlerinde önemli bir yere sahip olmuştur. Onun üç yüz kadar eser telif ettiği ancak bu eserlerin tamamının Basra'daki katliam (Zenc Ayaklanması 255/869) zamanında yakılıp yok edildiği rivayet edilmiştir. ${ }^{87}$ Günümüze ulaşmayan el-Müsnedü'l-Kebîr adlı eserinde 50 bin hadisin mevcut olduğu nakledilir. ${ }^{88}$

Eserleri:

Sezgin'in tespitlerine göre Nebîl'in günümüze ulaşan eserleri şunlardır:

1. Kitâbu'-Diyât: el-Hizânetü’t-Teymûriyye/Kahire Kütüphanesi hadis bölümüm 206 numaradadır. 35 varaktan oluşmaktadır. Kahire'de 1323 yılında basılmıştır.

2. Kitâbu'l-Evâil: Hz. Peygamber'in ilk olarak yaptığı işlerden bahsetmektedir. Eser, Şam Zâhiriyye Kütüphanesi 1/297 numarada, 1-24 varaklar arasında bulunmaktadır. ${ }^{89}$

3. Kitâbun fihi Zikru'd-Dünyâ ve'z-Zühdü fihâ ve 's-Samtu ve Hifzu'l-Lisânu ve'l-Uzlet: Zâhiriyye Kütüphanesi "Umumî Eserler" bölümünde bulunmaktadır. 20 varaktan ibarettir.

4. Kitâbu'l-Cihâd: Zâhiriyye Kütüphanesi mecmua nr. 6/15, 1: 74-106 varaklar arasindadir.

86 Saffet Köse, “İbn Dâvûd ez-Zâhirî”, XIX, s. 410-411; Kehhâle, Mu'cemü’l-Müellifinn, IX, s. 296.

87 Sezgin, a.g.e., I, s. 254. Daha geniş bilgi için bkz.: Ebu Nuaym, Ahmed b. Abdullah, Târîhu İsbehân (Ahbâru İsbehân), thk. Seyyid Kesrevi Hasan, I, Beyrut, Dâru'l-Kütübi'l-İlmiyye, 1990, s. 127; Zehebî, Tezkiretü'l-Huffâz, II, s. 158; İbn Kesîr, Ebu'l-Fidâ İsmail, el-Bidâye ve'n-Nihâye, XI, Beyrut, Dâru'l-Fikr, 1986, s. 84.

88 Ziriklî, el-'Alâm, I, s. 189.

89 Sezgin, a.g.e., I, s. 254. 
5. el-Müzekker ve't-Tezkîr ve'z-Zeker: Zâhiriyye Kütüphanesi mecmua nr. 60, 44-54 varaklar arasındadır. ${ }^{90}$

6. el-Âhâd ve'l-messânî. Bâsim Faysal Ahmed el-Cevâbire tarafindan yayımlanmıştır (I-VI, Riyad 1411/1991).

7. Avâli'l-Ehâdîs ve'l-E 'âlî ve Fevâidü'l-Harâiti ve'l-Leâlî: İmam Şâfî̂'nin mezhebini oluştururken istifade ettiği hadislerdir. Bu hadisleri Ebû Bekir en-Nebî toplamıştır. Sonraki dönemlerde Şâfiilerce fikıh baplarına göre tertip edilmiştir. Hamidiye Kütüphanesi nr. 1447, 133-147 vr. Bir nüshası bulunmaktadır. ${ }^{91}$

\subsection{Muâfâ b. Zekeriyya (ö. 390/1000) Mezhebi}

Sezgin'in müstakil mezhep imamları kategorisinde zikrettiği kişilerden biridir. Künyesi, Ebü'l-Ferec el-Muâfâ b. Zekeriyyâ b. Yahyâ en-Nehrevânî elCerîrî’ dir. Muâfâ, İbn Cerîr et-Taberî’nin ve onun mezhebinin en meşhur tâbilerindendir. Kaynaklarda onun pek çok ilimde mahir olduğu zikredilmiştir. 303/915 ya da 305/917 yılında, Bağdat ile Vâsıt arasındaki Nehrevan'da bir köyde doğmuştur. Ali İbrahim Nıftveyh ve başkalarından dersler almıştır. Fıkıh, Kur'an ve hadis ilimleri sahasında ve sarf, nahiv ve şiir gibi Arap dili ve edebiyatında devrin önemli simalarından biri kabul edilmiştir. Bir müddet, Bağdat'ın doğusunda bulunan Bâbu't-Tâk denilen yerde kadılık görevinde bulunmuştur. 390/1000 yılında Nehrevân' da vefat etmiştir. ${ }^{92}$

Eserleri:

1. el-Celîsü's-Sâlihu'l-Kâfî ve'l-Enîsü'n-Nâsıhu'ş-Şâfî. Muâfâ'nın bu eseri Serrâc'in (ö. 500/1106) Mesâriu 'l-Uş̧̧ak adlı eserinin önemli kaynaklarından biridir. Eser 100 meclis ihtiva eder. Her bir meclis bir hadis-i şerif ya da sahabi sözü ile başlar, ardından tarihî ve edebî ahbâr, kıssa ve şiirlerle açıklamalara yer verilir. Sezgin eserin pek çok yazma nüshasından bahseder. Bunların pek çoğu tam nüs-

90 Eser, Amr Abdülmun 'im Selim'in tahkikiyle, 1990 y1lında Mısır'da Dâru's-Sahâbe li’t-Turâs tarafindan neşredilmiştir.

91 Sezgin, a.g.e., I, s. 255. Ebu Bekir en-Nebîl ve eserleri hakkında daha geniş bilgi için bkz. Raşit Küçük, "İbn Ebu Âsım”, TDV İslâm Ansiklopedisi, XIX, İstanbul, 1999, s. 422-423.

92 Sezgin, a.g.e., I, s. 255. Daha geniş bilgi için bkz. İbnü'l-İmâd, Şezerâtü'z-Zeheb, III, s. 85, 4, 83; Zehebî, Târîhu'l-İslâm, XXVII, s. 206; Zehebî, Şemseddin Muhammed, el- 'İber fî Târîhi men Gaber, thk. Ebu Hacer Muhammed es-Said, II, Beyrut, Dâru'l-Kütübi'l-İlmiyye, t.y., s. 180; İbn Kesîr, el-Bidâye ve'n-Nihâye, XV, s. 132; İbn Hallikân, Vefeyâtü'l- 'Ayân, V, s. 211; İbnü'l-Kıftî, Ebu'l-Hasan Cemaleddin, İnbâhu'r-Ruvât, thk. Ebu'l-Fazl İbrahim, III, Beyrut, Dâru'l-Fikri'l-Arabî, 1982, s. 296; İbnü'l-Adîm, Ebu'l-Kâsım Kemâlüddin, Buğyetü 't-Taleb fî Târîhi Haleb, tkh. Süheyl Zekkâr, I, Beyrut, Dâru'l-Fikr, t.y., s. 25; Ahmet Özel, "Muâfâ en-Nehrevânî", TDV İslâm Ansiklopedisi, İstanbul, XXX, 2005, s. 306-308. 
ha olmayıp parça parçadır: Berlin, nr. 8325; Paris, nr. 3487; Damad İbrahim, nr. 282; Selim A ğa, nr. 480; Princeton, nr. 50, Zâhiriyye, nr. 4554, vd. ${ }^{93}$

2. Hadîs: Bir hadis cüzü olup Zâhiriyye Kütüphanesinde bir nüshası bulunmaktadır (Mecmua nr. 348).

\subsection{Cerîriyye Mezhebi}

Fuat Sezgin'in hakkında özel bir başlık açmadığı ancak satır arasında zikrettiği mezheplerden biridir. Bunun sebebi eserinin "Genel Tarih" bölümünde özel olarak zikredilmesidir. Sezgin' in dört fikıh mezhebinden sonra ortaya çıktığını ifade ettiği İbn Cerîr et-Taberî’nin (ö. 310/923) bu mezhebi, sınırlı bir bölgede yayılmış ve daha sonraları yok olup gitmiştir. ${ }^{44}$ Sezgin eserinin ilgili bölümünde Taberî ve mezhebi hakkında özetle şunları ifade eder: Künyesi, Ebû Ca'fer, ismi Muhammed b. Cerîr b. Yezîd et-Taberî'dir. 224 yılı sonunda veya 225 yılı başında (839) Taberistan'ın merkezi Âmül'de doğmuş, 310/923 yılında Bağdat'ta vefat etmiştir. Hayatının tamamını ilme veren Taberî eğitimin ilk yıllarını Rey'de geçirmiş sonra Bağdat'ta devam etmiştir. Ahmed b. Hanbel gibi muhaddis ve fakihlerden dersler almıştır. Bundan sonraki dönemlerde Basra Kûfe, Şam ve Mısır gibi ilim merkezlerinde bulunmuş ve eğitim hayatına devam etmiştir. Taberî kendini sadece hadis, fikıh, tefsir ve tarih gibi alanlarda yetiştirmekle kalmayıp Arap dili, matematik, tıp ve ahlak gibi ilimlerde de söz sahibi olacak kadar ilerlemiştir. Taberî önceleri Şâfiî mezhebine mensup iken Mısır'dan dönüşünden sonra kendi sistemini inşa etmiş ve mezhebine ona nispetle Cerîriyye denilmiştir. ${ }^{95}$

Eserleri:

1. Kitâbu Ahbâri'r-Rusuli ve'l-Mülûk (Târîhu'l-Ümem ve'l-Mülûk): Eser, Târîhu'r-Rusül ve'l-Enbiyâ' ve'l-Mülûk ve'l-Hulefâ', Târîhu't-Taberî isimleriyle de bilinmektedir. Sezgin eserin Türkiye'deki ve dünyanın çeşitli kütüphanelerinde cüzler, ciltler ve sahifeler halinde bulunan nüshalarını zikreder. Taberî’nin

93 Eser üzerine kısmî akademik çalışmalar da yapılmıştır. Daha geniş bilgi için bkz.: Ahmet Özel, "Muâfâ en-Nehrevânî", XXX, s. 306-308.

94 Sezgin, a.g.e., I, s. 255.

95 Sezgin, a.g.e., II, s. 642-643. Daha geniş bilgi için bkz.: Zehebî, Siyeru 'Alâmi'n-Nübelâ, XIV, s. 267; İbn Hallikân, Vefeyâtü'l- 'Ayân, IV, s. 191; İbnü'l-'İmâd, Şezerâtü'z-Zeheb, I, s. 26; İbnü'l-Cevzî, Cemâlüddin Ebu'l-Ferec, el-Muntazam fî Târîhi’l-Ümemi ve Mülûk, thk. Muhammed Abdülkadir Atâ, XIII, Beyrut, Dâru'l-Kütübi'l-İlmiyye, 1992, s. 215; İbn Kesîr, Ebu'l-Fidâ, el-Bedâye ve'n-Nihâye, thk. Abdullah et-Türkî, XIV, Misır, Dâru Hecer, 2003, s. 846; Hatîb el-Bağdâdî, Ebu Bekir Ahmed, Târîhu Bağdat, thk. Beşşar Avvâd, II, Beyrut, Dâru'l-Garbi'l-İslâmi, 2001, s. 548. 
günümüze tam olarak ulaşan eserlerinden biridir. İlk defa $M$. Jean de Goeje ile birlikte bir grup şarkiyatçının ortak çalışmasıyla neşredilmiştir (I-XV, Leiden 1879-1901). ${ }^{96}$

2. Zeylü'l-müzeyyel: 8-161 (629-778) arasında yirmi altı farklı yılda vefat eden bazı sahâbî ve tâbiînin isimlerine yer verilmiştir. ${ }^{97}$ Eser, el-Müntehab min Kitâbi Zeyli'l-müzeyyel adıyla yayımlanmıştır. ${ }^{98}$

3. Tehzîbü'l-Âsâr ve tafsîlü s-Sâbit 'an Resûlillâhi șallallahu 'aleyhi ve sellem mine'l-Ahbâr: İlk hadis ravileri olan sahabilerden başlamak suretiyle hadisleri Hz. Peygamber'den rivayet eden sahabilerin adlarına göre tanzim edilmiştir. Ayrıca eserde hadislerin illet ve sıhhat gibi özelliklerine de yer verilmiştir. Eserin tamamı günümüze ulaşmamış olup müsnedler halinde farklı zamanlarda parça parça neşredilmiştir. ${ }^{99}$

4. Câmi 'u'l-Beyân 'an Te 'vîli'l-Kur'ân: Taberî'nin tam olarak zamanımıza ulaşan diğer eseridir. En meşhur rivayet tefsirlerindendir. Sezgin bu eserin Türkiye ve dünya kütüphanelerinde bulunan yazmalarını zikreder. ${ }^{100}$ Eser ilk defa Mustafa b. Muhammed el-Bâbî el-Halebî tarafindan otuz bir cilt halinde Kahire'de hicri 1321 yılında basılmıştır. Daha sonraları pek çok tahkikli neşirleri ve diğer dillere çevirileri yapılmıştır.

5. İhtilâfü'l-Fukahâ: Eser Taberî'nin tamamı günümüze kadar ulaşamayan eserlerindendir. Kitabın elde mevcut olan bir bölümü 1902 yılında Alman şarkiyatçı Friedrich Kern tarafından tahkik edilip Kahire'de basılmış, bir başka bölümü de 1933 yılında Joseph Schacht tarafından Leiden'da basılmıştır. ${ }^{101}$

6. Tebsîrü Uli'n-Nühâ ve Me 'âlimi'l-Hüdâ: Akaide ait bir risâledir. ${ }^{102}$ Escorial Kütüphanesi'nde (nr. 6/1514) ve Revan Köşkü’nde (nr. 3/510) birer nüshas1 bulunmaktadır. Ali b. Abdülazîz b. Ali eş-Şibl tarafından neşredilmiştir (Riyad 1416/1996). ${ }^{103}$

96 Bkz.: Sezgin, a.g.e., II, s. 644-649.

97 Mustafa Fayda, “Taberî”, TDV İslâm Ansiklopedisi, XXXIX, İstanbul, 2010, s. 314-318.

98 Sezgin, a.g.e., II, s. 646.

99 Bkz. Mustafa Fayda, “Taberî”, XXXIX, s. 314-318.

100 Sezgin, a.g.e., II, s. 648-650.

101 Sezgin, a.g.e., II, s. 650.

102 Bkz. Mustafa Fayda, "Taberî”, XXXIX, s. 314-318.

103 Sezgin, a.g.e., II, 651. İbn Cerîr et-Taberî’ye nispet edilen diğer eserler için bkz. Mustafa Fayda, "Taberî", 39, XXXIX, s. 318. 


\subsection{Ahmed b. Kâmil (ö. 350/961) Mezhebi}

Sezgin'in hiçbir müçtehidin görüşlerini taklit etmediği ve kendine has fikhî görüşlerinin bulunduğunu ifade ettiği kişilerden biri de Ahmed b. Kâmil'dir. Künyesi, Ebû Bekr Ahmed b. Kâmil b. Halef b. Şecere el-Bağdâdî’dir. Müfessir, tarihçi ve dilcidir. 260/874 yılında doğmuştur. Muhammed b. Cerîr et-Taberî'den dersler almıştır. Daha sonraları ise kendi müstakil fıkhî mezhebini kurmuştur. Bir müddet Kûfe'de kadılık vazifesinde bulunmuştur. 350/961 y1lında vefat etmiştir. ${ }^{104}$

Eserleri:

1. el-Fevâidü'l-Hısân: Hz. Osman'ın faziletlerine dair bir risaledir. Zâhiriyye Kütüphanesi'nde (Mecmua nr. 72, vr. 1-7) bir nüshası bulunmaktadır. ${ }^{105}$

\section{Sonuç}

Tâbiîn devrinin sona ermesinin ardından hicri II. asrın başlarından IV. asrın sonlarına kadar İslam coğrafyasında pek çok amelî mezhep ortaya çıkmış ancak bunların pek az bir kısmı, halkın teveccühü ve talebelerinin gayreti gibi sebeplerden ötürü günümüze kadar ulaşabilmiştir. İslam hukuk tarihi ve literatürüne dair yazılan eserlerde, günümüze ulaşmayan mezheplerin sayısı ve metodolojilerine dair özlü bilgiler bulmak mümkündür. Ancak tam olarak mezhep kurucusu imamlar ve mezhepleri hakkında kesin bilgilere ulaşmak mümkün olmamıştır. $\mathrm{Bu}$ sebeple modern dönem çalışmalarında bu mezheplerin hangileri olduğuna dair çeşitli tasnifler yapılmış ve az bir kısmının sistematik mezhepler olduğu üzerinde ittifak edilebilmiştir.

Bu tür çalışmalardan biri de Fuat Sezgin'in Geschichte des arabischen Schrifttums (Leiden, 1967) olan ve Târîhu't-Turâsi'l-Arabî ismiyle Arapçaya çevrilen eseridir. Sezgin çalışmasının ilk cildinin üçüncü bölümünü fıkıh tarihi ve literatürüne ayırmış, bilinen dört mezhebi inceledikten sonra günümüze ulaşmayan mezhepleri zikretmiştir. Sezgin'in müstakil fikıh ekolleri adıyla yaşamayan sünnî mezheplere dair yaptığ tasnif, kendisinden sonra gelen tarih ve monografi yazarlarını etkilemiştir. Özellikle onun sünnî olup yaşamayan mezhepler hakkındaki

104 Sezgin, a.g.e., I, s. 257. Ahmed b. Kâmil'in tercüme-i hâli için bkz. İbn Nedîm, el-Fihrist, I, s. 51; İbn Meskiveyh, Ebu Ali Ahmed, Ebu Ali Ahmed b. Muhammed b. Yakub İbn Miskeveyh, thk. Ebu'l-Kâsım İmâmî, VI, Tahran, Seruş, 2000, s. 224; Zehebî, Târîhu'l-İslâm, XXV, s. 434; İbnü'l-'İmâd, Şezerâtü'z-Zeheb, IV, s. 260; Hatîb el-Bağdâdî, Târîhu Bă̆dat, V, s. 587; Kıftî, Inbâhu'r-Ruvât, I, s. 132.

105 Sezgin, a.g.e., 1, 258. Ahmed b. Kâmil'e nispet edilen diğer eserler için bkz. Abdurrahman Çetin, “Ahmed b. Kâmil”, TDV İslâm Ansiklopedisi, II, İstanbul, 1989, s. 96. 
tasnifi büyük ölçüde kabul edilmiş ve modern İslam hukuk tarihi eserlerindeki yerini almıştır. Sezgin çok bilinen Evzâî, İbn Ebî-Leylâ, Süfyân es-Sevrî, Leys b. Sa'd, Davud ez-Zâhirî, Cerîriyye Mezhebi gibi sünnî mezheplerin yanında, bir ekolü olup olmadığı bilinmeyen ya da ittifak edilmeyen İbn Eyyüb el-Abbâdânî, Yunus el-Eylî, İbn Yesâr, Yahyâ b. Âdem, Şüreyh b. Yûnus, Ebû Bekir Muhammed ez-Zâhirî, Nebîl (İbn Ebî Âsım), Muâfâ b. Zekeriyya, Ahmed b. Kâmil gibi fakihlerin mezheplerine de tasnifinde yer vermiştir. Esasen bunu kendisi de yer yer ifade etmektedir. Örneğin Davud ez-Zâhirî'yi müstakil bir mezhep olarak niteledikten sonra onun oğlunu ve Nebîl'i de bu kategori içinde zikretme ihtiyacı duymuştur. Sezgin, benzer mezhep sistematiği olan ya da aynı usul üzerine devam eden fakihleri de bu tasnifte zikretse de aslında o, bu fakihlerin daha sonraları kendi mezhebini kurduklarını yahut kullandığı yöntemin kendine mahsus olduğunu ifade etmek üzere böyle bir taksimata gitmiştir. Ahmed b. Kâmil örneğinde olduğu gibi; önceleri İbn Cerîr et-Taberî’nin öğrencisi iken daha sonraları kendi mezhep sistematiğini oluşturmuştur.

Sezgin'in tasnifi mutedil bir tasnif gibi durmaktadır. Ancak onun da tasnifi içinde, günümüz modern İslam hukuk tarihi hem de klasik dönem çalışmalarında ismi müstakil mezhep kurucusu olarak zikredilmeyen kişilere rastlamak mümkündür. Fakat Sezgin'in bu tasnifine, olan güvenden dolayıdır ki, günümüz bazı hukukçuları onun tasnifini aynen eserlerine taşımışlardır.

$\mathrm{Bu}$ çalışmanın hem Fuat Sezgin'in eserinin bilinip tanınmasına hem de çalıştı̆̆ımız konuyla ilgili detaylı çalışma yapacak olan araştırmacılara rehberlik edeceğini ümit ediyoruz. 


\section{Kaynakça}

El-Ahdab, Haldun, Zevâidu Târîhi Băgdat, Dımaşk, Dâru'l-Kalem, t.y.

Akpınar, Ömer Faruk, “Süfyân es-Sevrî’nin Hayatı ve Eserleri”, Usûl: İslam Araştırmaları, sayı 22, 2014.

Bilmen, Ömer Nasuhi, Hukukı İslamiyye ve Istılahatı Fıkhiyye Kamusu, İstanbul, Bilmen Yayınevi, t.y.

Buhârî, Muhammed b. İsmail, et-Târîhu'l-Kebîr, Haydarabad, Dâiretü'lMeârifi'l-Osmaniyye, t.y.

Carn, Frideric, İhtilâfu'l-Fukahâ (Mukaddime kısmı), Beyrut, Dârul'1Kütübi'l-İlmiyye, t.y.

Cezerî, Ebu'l-Hasan Ali, el-Lübâb fì Tehzîbi'l-Ensâb, Beyrut, Dâru's-Sader, 1980.

Ebu Nuaym, Ahmed b. Abdullah, Târîhu İsbehân (Ahbâru İsbehân), thk. Seyyid Kesrevi Hasan, Beyrut, Dâru'l-Kütübi'l-İlmiyye, 1990.

Fayda, Mustafa, “Taberî”, TDV İslâm Ansiklopedisi, İstanbul, 2010.

Hacvî, Muhammed b. Hasan b. Arabi es-Seâlibî, el-Fikru's-Sâmî fì Târîhi Fıkhi'l-İslâmî, Rabat, Matbaatü İdâretü'l-Meârif, 1340.

Hallâf, Abdülvehhab, 'İlmu Usûli'l-Fikh ve Hulâsatu Târîhu't-Teşri', Misır, Matbaatü'l-Medenî, t.y.

Hatib el-Bağdadî, Ahmed b. Ali, Târîhu Bağdat, Beyrut, Dâru'l-Kütübi'l-ìlmiyye, t.y.; Beyrut, Dâru'l-Garbi'l-İslâmi, 2001.

Hudari Beg, Muhammed, Târîhu't-Teşrîi'l-İslâmî, Beyrut, Dâru'l-Kütübi'l-İlmiyye, 2018.

, Târîhu't-Teşrîi'l-İslâmî, Beyrut, Dâru'l-Fikr, 1967.

İbn Âbidîn, Muhammed Emin, Şerhu'l-Manzûmeti Ukûdi Resmi'l-Müftî, Haydarabad, 2000.

İbn Asâkir, Ebu'l-Kâsım Ali, Târîhu Medîneti Dımaşk, thk. Amr b. Garâme, Beyrut, Dâru'l-Fikr, 1995.

İbn Ebî Hâtim, Ebu Muhammed Abdurrahman, el-Cerh ve't-Ta 'dîl, Beyrut, Dâru İhyâi't-Türâsi'l-Arabî, 1952.

İbn Hacer el-Askalânî, Ebü'l-Fazl Şihâbüddîn Ahmed, Tehzîbu 't-Tehzîb, Hindistan, Dâru Matbaati'l-Mearif, 1326. , Lisânü'l-Mîzân, Beyrut, Müessesetü'l-Alemi, 1971. 
İbn Hallikan, Ebu'l-Abbas Şemseddin, Vefâyâtü'l-'Ayân ve Enbâu Ebnâi'z-Zamân, thk. İhsan Abbas, Beyrut, Dâru Sader, 1994.

İbn Hazm, Ebû Muhammed Ali, el-İhkâm fî Usûli'l-Ahkâm, thk. Ahmed Muhammed Şakir, Beyrut, Dâru'l-Afâki'l-Cedide, t.y.

İbn Kayyim el-Cevziyye, Ebu Abdullah Muhammed, I'lâmu'l-Muvakkl 'în an Rabbi'l-Âlemîn, Suudi Arabistan, Dâru İbnü'l-Cevzî, 1423.

İbn Kesîr, Ebu'l-Fidâ İsmail, el-Bidâye ve'n-Nihâye, Beyrut, Dâru'l-Fikr, 1986; Misır, Dâru Hecer, 2003.

Merkezü'n-Numan, 2011. ,et-Tekmîl fi'l-Cerhi ve't-Tadîl, thk. Şadi b. Muhammed, Yemen,

İbn Kuteybe, Ebû Muhammed Abdullah b. Müslim ed-Dineverî, el-Maarif, thk. Servet Ukkâşe, Kahire, Heyetü'l-Amme Misriyye, 1992.

İbn Miskeveyh, Ebu Ali Ahmed b. Muhammed b. Yakub, Tecâribu'l-Ümem, thk. Ebu'l-Kâsım İmâmî, Tahran, Seruş, 2000.

İbn Nedîm, Ebu'l-Ferec Muhammed, el-Fihrist, thk. İbrahim Ramazan, Beyrut, Dâru'l-Marife, 1997.

İbn Sa'd, Ebû Abdullah Muhammed, et-Tabakatü'l-Kübrâ, Beyrut, Daru's-Sader, t.y. Kütübi'l-İlmiyye, 1990.

, et-Tabakâtü'l-Kübrâ, thk. Abdulkadir Atâ, Beyrut, Dâru'l-

İbnü'l-Adîm, Ebu'l-Kâsım Kemâlüddin, Buğyetü 't-Taleb fî Târîhi Haleb, tkh. Süheyl Zekkâr, Beyrut, Dâru'l-Fikr, t.y.

İbnü'l-Cellâb, Ebu'l-Kâsım Ubeydullah, et-Tefri', thk. Hüseyin b. Salih el-Hemedânî, Beyrut, Dâru'l-Garbi'l-İ̀slâmî, 1987.

İbnü'l-Cevzî, Cemâlüddin Ebu'l-Ferec, el-Muntazam fî Târîhi'l-Ümemi ve Mülûk, thk. Muhammed Abdülkadir Atâ, Beyrut, Dâru'l-Kütübi'l-İlmiyye, 1992.

İbnü'l-İmâd, Ebü'l-Felâh Abdülhay b. Ahmed b. Muhammed es-Sâlihî elHanbelî, Şezerâtü'z-Zeheb fì Ahbâri men Zeheb, thk. Mahmud Arnavut, Beyrut, Dâru İbn Kesîr, 1986.

İbnü'l-Kıftî, Ebu'l-Hasan Cemaleddin, İnbâhu'r-Ruvât, thk. Ebu'l-Fazl İbrahim, Beyrut, Dâru'l-Fikri'l-Arabî, 1982.

İbnü'l-Müstevfi, el-Mübârek b. Ahmed, Târîhu Erbil, thk. Sami b. Seyyid Hammas, Irak, Dâru'r-Reşîd, 1980. 
Karaman, Hayrettin, İslam Hukuk Tarihi, İstanbul, İz Yayınc1lı, 2011.

Kehhâle, Ömer Rızâ, Mu 'cemü’l-Müellifinn, Beyrut, Mektebetü’l-Müsennâ, t.y.

El-Kerecî, Ebu Hasan el-Fusûl fi'l-Usûl ani'l-Eimmeti'l-Fuhûl, thk. Salih b. Abdülaziz es-Sindî, Beyrut, Dâru'l-Lü’lü, t.y.

Kinalızade, Alaeddin Ali b. Emrullah, Muhtasar fi Zikri Tabakati'l-Hanefiyye, Köprülü Yazma Eser Kütüphanesi, Hafız Ahmed Paşa Koleksiyonu, 34 Ha $330 / 15$.

Köse, Saffet, "İbn Dâvûd ez-Zâhirî", TDV İslâm Ansiklopedisi, İstanbul, 1999.

Küçük, Raşit, “İbn Ebu Âsım”, TDV İslâm Ansiklopedisi, İstanbul, 1999.

Leknevî, Abdülhay, en-Nâfiu'l-Kebîr limen Yutâli ' el-Câmiu's-Sagîr, Beyrut, Alemu'l-Kutub, 1986.

Makdisi, George, "İslam Hukuk Tarihinde Sünnî Mezheplerin Rolü”, Recep Tayyip Erdoğan Üniversitesi Illahiyat Fakültesi Dergisi, çev. Yakup Mahmutoğlu, 5, 2014.

Medkûr, Muhammed Sellâm, el-Medhal li'l-Fıkhi'l-İslâmî, Kahire, Dâru'l-Kitâbu'l-Hadîs, 1996.

Melchert, Christopher, "Sünnî Fıkıh Mezheplerinin Teşekkülü”, M.Ü. İlahiyat Fakültesi Dergisi, çev. Nail Okuyucu, 41, 2011/2.

Mizzî, Yusuf b. Abdurrahman, Tehzîbu 'l-Kemâl fî Esmâi'r-Ricâl, thk. Beşşar Avvad, Beyrut, Müessesetü'r-Risâle, 1980.

Muhammed Ebu Zehre, Muhammed b. Ahmed b. Mustafa, Ebû Hanîfe Hayatuhu ve Asruhu Ârâuhu ve Fıkhuhu, Misır, Dâru'l-Fikri'l-Arabi, t.y.

Nesâî, Ebû Abdurrahman Ahmed el-Horasânî, Tesmiyettü Fukahâi'l-Emsâr, thk. Mahmud İbrahim Zayed, Halep, Dâru'l-Va'y, 1369.

Özdirek, Recep - Çavuşoğlu, Ali Hakan, "Süfyan es-Sevri”, TDV İslâm Ansiklopedisi, İstanbul, 2010.

Özel, Ahmet, "Muâfâ en-Nehrevânî”, TDV İslâm Ansiklopedisi, İstanbul, 2005.

Özen, Şükrü, “İbn Süreyc”, TDV İslam Ansiklopedisi, İstanbul, 1999.

Özer, Hasan, "İbn Kemal ve Tabakatü'l-Fukaha Adlı Eseri (tahkikli neşir)”, İslam Hukuku Araştırmaları Dergisi, , sayı 14, Konya, 2009. 
Sezgin, Fuat, Târîhu't-Türâsi'l-Arabî (GAS), Arapçaya çeviren Mahmud Fehmî Hicâzî, Riyad, Câmiatü el-İmam Muhammed b. Suud el-İslamiyye, 1991.

Sibt İbnü'l_Cevzî, Şemseddin Ebu'l-Muzaffer, Mir'âtü'z-Zamân fì Tevârîhi'l- 'Ayân, Dımaşk, Dâru'r-Risâle el-Alemiyye, 2013.

Suyûtî, Celaleddin, el-Hâvî li'l-Fetâvî, thk. Abdüllatif Hasan, Beyrut, Dâru'lKütübi'l-İlmiyye, 2005.

Şaban Muhammed İsmail, el-Medhal li Dirâseti'l-Kur'ân ve’s-Sünnet ve'l-Ulûmi 'l-İslamiyye, Halep, Dâru'l-Ensar, t.y.

Şarânî, Abdülvehhab b. Ahmed, el-Mîzânü'l-Kübra, Beyrut, Dâru'l-Kütübi'l-İlmiyye, 2018.

Eş-Şelebî, Muhammed Mustafa, el-Medhal fi't-Ta 'rîfi bi’l-Fıkhi'l-İslâmî, M1sir, Dâru’t-Te'lîf, 1962. , el-Medhal fi'l-Fıkhı'l-íslâmî, Beyrut, Dâru'l-Câmiiyye, 1985.

Şener, Abdülkadir, "İslâmda Mezhepler ve Hukuk Ekolleri”, Ankara Üniversitesi Illahiyat Fakültesi Dergisi, cilt XXVI, 1983.

Şîrâzî, Ebu İshak, Tabakâtü'l-Fukahâ, thk. İhsan Abbas, Beyrut, Dâru'r-Râid el-Arabî, 1970.

Taberî, Muhammed b. Cerîr, Târîhu 't-Taberî, Beyrut, Dâru’t-Türâs, 1387.

Tarîfî, Nasr b. Akil b. Casir, Târîhu'l-Fıkhi'l-İslâmî, Riyad, Mektebetü’t-Tevbe, 1997.

Taşköprizâde Ahmed Efendi, Tabakâtü'l-Fukaha, nşr. Ahmed Nîle, Musul, 1961.

Tekin, Abdülkadir, "Süfyan es-Sevrî’nin Fıkıhçıllı̆ı”, Amasya Illahiyat Dergisi, say1 5, 2015.

Ünalan, Abdülkerim, “İslam Hukuku ve Ana Özellikleri”, Dicle Üniversitesi İlahiyat Fakültesi Dergisi, c. 1, Diyarbakır, 1999.

Zehebî, Şemsüddin Muhammed, Târîhu'l-İslâm ve Vefeyâtü'l-Meşâhîri ve'lA 'lâm, thk. Ömer Abdüsselam Tedmürî, Beyrut, Dâru'l-Kitâbi'l-Arabî, 1993. sesetü’r-Risale, 1985.

, Siyeru A 'lâmi'n-Nübelâ, thk. Şuayb el-Arnavut, Beyrut, Mües, Siyeru A'lâmi'n-Nübelâ, Kahire, Dâru'l-Hadîs, 2006; Müessesetü'r-Risâle, 1985. , Tezkiretü'l-Huffâz, Beyrut, Dâru’t-Turâsi'l-‘Arabî, 1374. 
, el-'Íber fì Târîhi men Ğaber, thk. Ebu Hacer Muhammed es-Said, Beyrut, Dâru'l-Kütübi'l-İlmiyye, t.y.

Zekeriyyâ el-Ensârî, Ebu Yahya Zeynüddin, Esnâ'l-Metâlib fí Şerhi Ravzi 't-Tâlib, thk. Muhammed Tamir, Beyrut, Dâru'l-Kütübi'l-İlmiyye, 2000.

Zeydan, Abdülkerim, el-Medhal li Dirâsâti'ş-Şerîati'l-İslâmiyye, İskenderiye, Dâru Ömer b. Hattab, 2001. , el-Vecîz fì Usûli'l-Fıkh, Beyrut, Müessesetü Kurtuba, 1987.

Ziriklî, Hayreddin, el- 'Alâm, Beyrut, Dâru'l-İlim li'l-Melâyîn, 2002.

Ez-Zuhayli, Muhammed Mustafa, el-Vecîz fì Usûli'l-Fıkhi'l-İslâmî, Dımaşk, Dâru'l-Hayr, 2006. 